Cristina Maria Meireles Campofiorito

\title{
Correlação dos ligantes de quimiocinas e de seus respectivos receptores em relação à invasão de linfonodos nos carcinomas epidermóides em cabeça e pescoço
}

Tese apresentada à Faculdade de Medicina da Universidade de São Paulo para obtenção do Título de Doutor em Ciências

Área de concentração: Oncologia Orientadora: Prof $^{\mathrm{a}} \mathrm{Dr}^{\mathrm{a}}$ Miriam Hatsue Honda Federico

São Paulo

2006 
Dados Internacionais de Catalogação na Publicação (CIP)

Preparada pela Biblioteca da

Faculdade de Medicina da Universidade de São Paulo

Creprodução autorizada pelo autor

Campofiorito, Cristina Maria Meireles

Correlação dos ligantes de quimiocinas e de seus respectivos receptores em relação à invasão de linfonodos nos carcinomas epidermóides em cabeça e pescoço / Cristina Maria Meireles Campofiorito. -- São Paulo, 2006.

Tese(doutorado)--Faculdade de Medicina da Universidade de São Paulo.

Departamento de Radiologia.

Área de concentração: Oncologia.

Orientadora: Miriam Hatsue Honda Federico.

Descritores: 1.Carcinoma de células escamosas 2.Neoplasias de cabeça e pescoço 3.Quimiocinas 4.Receptores de quimiocinas 5.Receptores CXCR4 6.Linfonodos

USP/FM/SBD-429/06 
Dedicatória 
Ao meu pai pelo sonho e entusiasmo. Aos meus filhos e meu marido pelo incentivo, paciência e carinho. À minha mãe pelo dom da vida. 


\section{Agradecimentos}


À Profa. Dra. Miriam Hatsue Federico pela paciência, compreensão, por seu exemplo e por ser a grande responsável pela realização deste trabalho,

Á Profa Dra. Maria Mitzi Brentani pela oportunidade de estudar nesta pósgraduação em oncologia e trabalhar no laboratório de oncologia experimental,

Aos colegas de trabalho, Fátima Solange Pasini, Simone Maistro, Karen Cristina Brunialti, Lílian Pires Barbeta, Bruno Ferencz Papp Cadima pela cooperação e ajuda neste trabalho,

Um agradecimento muito especial para a amiga Flávia Regina Rotea Mangone por toda a sua ajuda na realização deste trabalho, desde a metodologia até correção desta tese,

Aos Drs. Carlos N. Lenh e Fernando Walder pela colaboração imprescindível para a realização deste trabalho,

Ao Dr. Igor Moisés Longo Snitcovisky pelas idéias e apoio,

A todos os colegas de trabalho do laboratório de Oncologia Experimental pela ajuda, cooperação e amizade,

À CAPES pela bolsa de estudos e à FAPESP (processo No2005/04134-5) pelo apoio financeiro na pesquisa. 
Sumário 


\section{Sumário}

\section{Lista de Unidades e Abreviaturas}

\section{Lista de Figuras}

\section{Lista de Tabelas}

1- Introdução

2- Objetivos 13

2.1- Objetivo Geral

2.2- Objetivos Específicos $\ldots 14$

3- Métodos 15

3.1- Casuística

3.2- Extração do RNA total

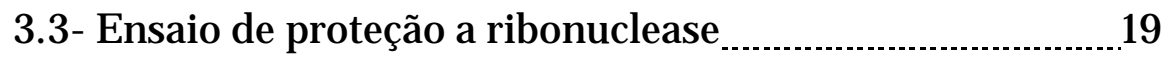

3.3.1- Síntese de sondas _ _ _ 21

3.3.2- Preparação do RNA e hibridização ………................ 22

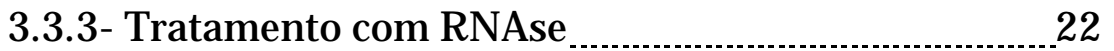

3.3.4- Resolução em gel das sondas protegidas _.................. 24

3.4- RT-PCR em tempo real

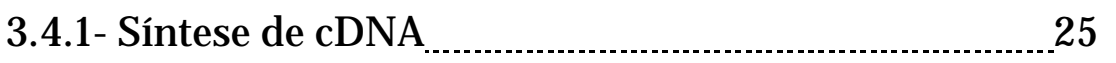

3.4.2- PCR em tempo real

3.5- Correlações estatísticas _.......................................... 28

4- Resultados

4.1- Determinação da Expressão dos mRNA dos

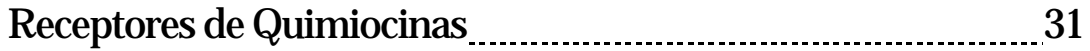

4.2- Análise de sobrevida global e livre de doença _.................45

4.3- Análise dos ligantes de quimiocinas ............................... 51

5- Discussão

6- Conclusões

7- Referências 66

Apêndice I

Apêndice II 
Lista de Unidades e Abreviaturas 


\section{LISTA DE UNIDADES}

\begin{tabular}{|c|c|}
\hline $\begin{array}{ll}\text { - } & \mu g \\
\text { - } & \mu L \\
\text { - } & \mu \mathrm{M} \\
\text { - } & \mathrm{bp} \\
\text { - } & \mathrm{cpm} \\
\text { - } & \mathrm{g} \\
\text { - } & \mathrm{M} \\
\text { - } & \mathrm{ng} \\
\text { - } & \mathrm{nm} \\
\text { - } & \mathrm{nM} \\
\text { - } & \mathrm{rpm}\end{array}$ & $\begin{array}{l}\text { micrograma } \\
\text { microlitro } \\
\text { micromolar } \\
\text { pares de bases } \\
\text { contagens por minuto } \\
\text { grama } \\
\text { molar } \\
\text { nanograma } \\
\text { nanômetro } \\
\text { nanomolar } \\
\text { rotações por minuto }\end{array}$ \\
\hline
\end{tabular}

\section{LISTA DE ABREVIATURAS}

- cDNA ácido desoxiribonucléico complementar

- DEPC dietilpirocarbonato

- DNA ácido desoxiribonucléico

- DTT dietiltreitol

- HNSCC carcinoma de célula escamosa de cabeça e pescoço

- INCA Instituto Nacional do Câncer

- PCR reação em cadeia da polimerase

- $\mathbf{p N}+\quad$ pacientes com metástase em linfonodos

- pNo pacientes sem metástase em linfonodos

- mRNA ácido ribonucléico mensageiro

- RNAt ácido ribonucléico transportador

- RNAse Ribonuclease

- RPA Ensaio de Proteção à Ribonuclease

- RT Transcrição Reversa

- UV ultravioleta

- Vs versus

- U Uracila

- G Guanina

- A Adenina

- C Citosina

- TEMED tetrametiletilenodiamina

- TBE Tampão Tris- $\mathrm{HCl}$, ácido bórico e EDTA

- DNTPs desoxinucleotídeo-trifosfatos

- $\mathrm{MgCl}_{2} \quad$ Cloreto de Magnésio

- DMSO Dimetilsulfóxido 
Lista de Figuras 
Figura 1

pág 06

Esquema representativo de possíveis alvos de metástase em câncer de mama.

Figura 2 pág 31

Autorradiograma de um ensaio representativo mostrando a expressão dos mRNA dos receptores de quimiocinas em HNSCC pelo método de RPA.

Figura 3

\section{3.}

Expressão dos mRNA de receptores de quimiocinas em HNSCC.

Figura 4

Expressão do mRNA do receptor de quimiocina CXCR4, no grupo como um todo e nos sítios de carcinoma epidermóide de cabeça e pescoço.

Figura 5

Expressão dos mRNA de receptores de quimiocinas nos sítios de carcinoma epidermóide de cabeça e pescoço.

Figura 6 Comparação da expressão do mRNA de pág 41 receptores de quimiocinas entre tumores pNO e $\mathrm{pN}+$ em HNSCC, boca, laringe, orofaringe e hipofaringe.

Figura 7 pág 43

Comparação da média e desvio padrão relativos á expressão do RNA mensageiro dos receptores de quimiocinas entre tumores e linfonodos comprometidos em HNSCC.

Figura 8

$$
\text { comprometidos em HNSCC. }
$$

"Expressão dos mRNA de receptores de quimiocinas em HNSCC.

Figura 9

Curvas de sobrevida global de pacientes portadores de HNSCC.

Figura 10

Curvas de sobrevida livre de doença de pacientes portadores de HNSCC.

Figura 11

Curvas de sobrevida global de pacientes portadores de carcinoma epidermóide de cavidade oral.

Figura 12

Curvas de sobrevida livre de doença de pacientes portadores de carcinoma epidermóide de cavidade oral.

Figura 13 .pág 53

Expressão relativa do ligante de quimiocinas $\mathrm{CX}_{3} \mathrm{CL1}$ comparando a expressão entre tumores primários e linfonodos comprometidos. 
Lista de Tabelas 
Tabela 1 pág 18

Características clínico-patológicas dos pacientes portadores de HNSCC, submetidos à cirurgia terapêutica no Hospital Heliópolis, utilizados na determinação da expressão dos mRNAs dos receptores de quimiocinas por RPA.

Tabela 2 pág 27

Descrição dos Oligonucleotídeos utilizados no ensaio de PCR em tempo real.

Tabela 3 Comparação da média e desvio padrão relativos á expressão do RNA mensageiro dos receptores de quimiocinas entre tumores e mucosa adjacente, considerados entre todos os sítios tumorais estudados.

Tabela 4 Comparação da média e desvio padrão relativos á expressão do RNA mensageiro dos receptores de quimiocinas entre tumores e mucosa normal adjacente, considerados entre tumores pT1/T2 e pT3/T4.

pág 33

pág 37

Tabela 5 pág 39

Comparação da nédia e desvio padrão relativos á expressão do RNA mensageiro dos receptores de quimiocinas entre tumores pT1/T2 e pT3/T4.

Tabela 6 Comparação da média e desvio padrão relativos pág 42 á expressão do RNA mensageiro dos receptores de quimiocinas entre tumores pNO e pN.

Tabela 7 pág 43

Comparação da média e desvio padrão relativos á expressão do RNA mensageiro dos receptores de quimiocinas entre tumores e linfonodos comprometidos em HNSCC. 


\section{RESUMO}

Campofiorito CMM. Correlação dos ligantes de quimiocinas e de seus respectivos receptores em relação à invasão de linfonodos nos carcinomas epidermóides em cabeça e pescoço [Tese]. São Paulo: Faculdade de Medicina da Universidade de São Paulo; 2006. 73p.

Tanto a invasão local como o comprometimento de linfonodos cervicais tem grande impacto na sobrevida de pacientes portadores de carcinomas epidermóides de cabeça e pescoço. Em nosso trabalho nós primeiramente determinamos a expressão dos receptores de quimiocinas de CXCR1 a CXCR5, além de CCR7 e $\mathrm{CX}_{3} \mathrm{CR} 1$ pelo método do ensaio de proteção à ribonuclease (RPA) em 98 fragmentos de tumores primários, 91 fragmentos de mucosas adjacentes e 26 linfonodos comprometidos e correlacionamos estes dados com parâmetros anátomo-patológicos e sobrevida. CXCL12 ligante do receptor CXCR4 e CCL19 e CCL21 ambos ligantes de CCR7 foram determinados em 38 fragmentos de tumores, 33 mucosas adjacentes e 25 linfonodos comprometidos pela técnica de real-time PCR. Os tumores primários apresentam expressão aumentada do mRNA de CXCR1 $(P=0.013), \quad$ CXCR3 $(P=0.008)$ e CXCR4 $(P=0.025)$. Não observamos correlações entre status linfonodal ou tamanho de tumor. Os linfonodos comprometidos expressam mais mRNA dos receptores de quimiocinas CXCR4, CXCR5, CCR7 e CX ${ }_{3} \mathrm{CR} 1$ (todos com $\mathrm{P}<0.0001$ ) em comparação aos tumores comprometidos. Observamos um aumento de sobrevida $(P=0.048)$ e uma tendência a aumento de sobrevida livre de doença $(P=0.074)$ nos pacientes negativos para a expressão de $C X_{3} C R 1 \quad(n=17)$ em comparação aos pacientes positivos $(n=21)$ somente no subgrupo de pacientes portadores de carcinomas da cavidade oral. $\mathrm{O}$ mesmo foi observado com os pacientes CCR7 negativos também no subgrupo de pacientes portadores de carcinomas da cavidade oral, tanto em sobrevida global $(P=0.024)$ como para sobrevida livre de doença $(P=0.049)$. Em relação aos ligantes de quimiocinas observamos um aumento do mRNA de CCL21 em linfonodos comprometidos em relação aos tumores primários $(P=0.059)$. Concluímos que a interação quimiotática entre CCR7 e de seu ligante CCL21, poderia ser um mecanismo de atração de células tumorais para os linfonodos em tumores de cavidade oral, além disso a negatividade da expressão do mRNA de $\mathrm{CCR} 7$ e $\mathrm{CX}_{3} \mathrm{CR} 1$ são candidatos marcadores de uma melhor sobrevida em carcinomas epidermóides de cavidade oral.

Descritores: 1-Carcinoma de células escamosas, 2-Neoplasia de cabeça e pescoço, 3-Quimiocinas, 4-Receptores de Quimiocinas, 5-Receptores CXCR4, 6-Linfonodos. 


\section{SUMMARY}

Campofiorito, CMM. Correlation of chemokine ligands and its receptors with lymph node metastasis in Head and Neck Squamous Cell Carcinoma [Thesis]. São Paulo: "Faculdade de Medicina da Universidade de São Paulo"; 2006. 73p.

Local invasion and lymph nodal spread impact in the outcome of Head and Neck squamous cell carcinoma (HNSCC) patients (pts). We determined CXCR1-5, CCR7 and $\mathrm{CX}_{3} \mathrm{CR} 1$ mRNA expression by means of RNAse protection assay in $98 \mathrm{HNSCC}$ primary tumors and 91 adjacent mucosa and 26 metastatic lymph nodes, correlating this data with outcome. CXCL12 and CCL19/CCL21, ligands for CXCR4 and CCR7, were determined in 38 tumor fragments, 33 adjacent mucosas and 25 de metastatic lymph nodes, by means of Quantitative Real-Time PCR. Tumors presented higher CXCR1 $(P=0.013)$, CXCR3 $(P=0.008)$ and $C X C R 4$ mRNA $(P=0.025)$ expression as compared to mucosa. No correlations are observed neither lymph nodal status nor tumor size impacted on chemokine receptor expression. Metastatic lymph nodes expressed more CXCR4, CXCR5, CCR7 and $\mathrm{CX}_{3} \mathrm{CR} 1 \quad(\mathrm{P}<0.0001)$ as compared to matched tumors. We found a longer overall survival $(\mathrm{OS})(\mathrm{P}=0.048)$ and a trend toward longer disease free survival (DFS) $(P=0.074)$ in $C X_{3} C R 1$ negative $(n=17)$ as compared to positive pts $(n=21)$ only in oral subgroup. The same occurred for CCR7 negative oral SCC, in terms of OS ( $P=0.024)$ and DFS $(P=0.049)$. We conclude that, of the chemokine receptors here studied, CCR7 and $\mathrm{CX}_{3} \mathrm{CR} 1$ mRNA expression seems to better reflect outcome in oral subsite only. In addition, CCL21, a CCR7 ligand mRNAs is more expressed in metastatic lymph nodes than tumors $(P=0.059)$. Further studies are warranted to confirm these results.

Descriptors: 1-Carcinoma, Squamous Cell, 2- Head and Neck Neoplasms, 3Chemokines, 4-Receptors, Chemokine, 5-Receptors CXCR4, 6- Lymph Nodes 


\section{Introdução}




\section{1- Introdução}

O câncer de cabeça e pescoço apresenta, ainda hoje, alta incidência em todo mundo. Em 2002, a incidência mundial deste tipo de câncer foi de 563.826 casos com 301.408 mortes (Parkin et al. 2005). Nos Estados Unidos, por exemplo, as estimativas para o ano de 2006 foram de 40.500 casos novos desse câncer, com aproximadamente 11.170 óbitos. No Brasil, só o câncer de boca representa aproximadamente $5 \%$ de todos os tipos de câncer e a estimativa para 2006 foi de 13.470 casos novos: entre os homens, 10.060 casos e entre as mulheres, 3.410 casos. Para a Região Sudeste do Brasil foram estimados 7.680 casos, sendo 4.330 casos somente no estado de São Paulo. O câncer de laringe soma $2 \%$ de todos os tipos de câncer no Brasil e representa $25 \%$ dos casos de câncer de cabeça e pescoço (Inca, 2006; Jemal et al. 2006).

Dados do Projeto de implantação do Registro Hospitalar de Câncer RHC do Hospital das Clínicas da FMUSP indicaram que, no ano de 2000, $8 \%$ de todos os casos de câncer atendidos na instituição eram de pacientes com câncer de cabeça e pescoço (FAPESP/ Projeto 99/07516-3 - em preparo para publicação). Além da mortalidade alta, esse câncer apresenta também alta morbidade devido a problemas funcionais e diferenças estéticas causados pelo próprio câncer ou por seu tratamento (Inca, 2006; SPOHNC, 2004). No Brasil, como em vários países, a maioria desses pacientes chega ao médico com a doença avançada e aproximadamente $65 \%$ já apresentam comprometimento ganglionar à primeira consulta, fator este que piora o prognóstico desses pacientes (UICC, 1999). 
O tratamento do câncer de cabeça e pescoço requer a avaliação de um grupo multidisciplinar. Em geral, o tratamento consiste em cirurgia, cirurgia mais radioterapia ou radioterapia, sendo esta última associada ou não a quimioterapia. Muitas vezes, a cirurgia local compreende também uma linfadenectomia cervical, sempre que os linfonodos estiverem comprometidos ou houver suspeita do seu comprometimento. Os pacientes, mesmo operados com intenção curativa, podem apresentar alterações ou até perda da fala, alterações de olfato e mastigação, além de problemas estéticos, dependendo da localização e da extensão da doença, o que faz com que a qualidade de vida como um todo possa piorar (Abeloff et al. 2000; UICC, 1999; SPOHNC, 2002).

O óbito, quando ocorre, quase sempre vem como conseqüência de recidiva local, o que em geral ocorre nos primeiros 2 ou 3 anos e apenas 32 a $55 \%$ dos pacientes tratados com intenção curativa permanecem vivos após cinco anos do diagnóstico (UICC, 1999; Vokes et al. 1997; Landis et al. 1999).

Os pacientes com linfonodos acometidos apresentam metade do tempo de sobrevida daqueles sem metástases e o prognóstico destes pacientes, piora com a extensão crescente das metástases ganglionares (UICC, 1999).

Pelo já exposto, o principal fator prognóstico é a presença ou não de acometimento ganglionar regional. Apesar de muito estudados, os mecanismos determinantes das, por assim dizer, metástases ganglionares são ainda pouco claros. A metástase é um processo complexo, constituído de várias etapas, o qual resulta das interações entre as células tumorais e o 
microambiente tecidual onde estas células se encontram. Durante a disseminação de um tumor, as células tumorais devem ser capazes de se soltar do tumor primário (perda da interação célula-célula) e escapar do tecido de origem; invadir a matriz extracelular, migrar ativamente pelo estroma intersticial; induzir a formação de novos vasos sanguíneos e/ou linfáticos (angiogênese), essenciais para a expansão da massa tumoral e por estes mesmos vasos, as células tumorais podem alcançar a corrente sanguínea ou linfática após atravessar a membrana basal e o endotélio dos vasos (intravasão), sobreviver na circulação, interagir com o endotélio vascular, extravasar e ainda, proliferar no parênquima do órgão-alvo. (Bases da Oncologia, 2003).

Existem três teorias básicas que tentam explicar a formação de metástases. A primeira teoria propõe que as células tumorais saiam para a corrente sanguínea e linfática e, conseqüentemente, para todos os órgãos e se multiplicam somente naqueles órgãos que possuem fatores de crescimento apropriados. De acordo com a segunda teoria, as células endoteliais dos vasos sanguíneos dos órgãos alvo expressam moléculas de adesão que fazem com que as células tumorais que estão presentes na circulação parem nestes órgãos, produzindo a metástase. Finalmente, a teoria da quimioatração propõe que as células tumorais possuam receptores de quimiocinas e migrem para diferentes órgãos, dependendo da produção de quimiocinas por esses órgãos (Figura 1, Liotta, 2001).

Esse mecanismo de quimioatração seria o mesmo usado pelas células pluripotentes sanguíneas. Sabe-se que quimiocinas parecem mediar à movimentação de leucócitos para os tecidos, sendo essenciais no 
processo inflamatório e na resposta à infecção e vacinas. Até o momento já estão descritas mais de cinqüentas quimiocinas e dezoito receptores. As quimiocinas que parecem ter papel nesse processo pertencem a uma família de proteínas homólogas com 8 a $10 \mathrm{kDa}$, subdivididas em quatro famílias: $\mathrm{CXC}, \mathrm{CC}, \mathrm{XC}$ e $\mathrm{CX}_{3} \mathrm{C}$ subdivididas com base na posição relativa dos resíduos de cisteína na proteína. Nas quimiocinas CXC os primeiros dois resíduos de cisteína são separados por um aminoácido simples, enquanto que nas quimiocinas $\mathrm{CC}$ os dois primeiros resíduos de cisteína são adjacentes, as quimiocinas $\mathrm{XC}$ perderam um dos resíduos de cisteína e finalmente, as quimiocinas $\mathrm{CX}_{3} \mathrm{C}$ contém três aminoácidos entre duas cisteínas (Luster, 1998; Murphy, 2001; Liotta, 2001; Zlotnik, 2004, Kulbe et al. 2004, Kakinuma e Hwang , 2006).

Essas quimiocinas induzem, através de interação com receptores acoplados à proteína $\mathrm{G}$, reorganização citoesqueletal, firme adesão com células endoteliais e migração direcional. Acredita-se que essas proteínas secretadas possam agir coordenadamente com proteínas da superfície celular, tais como as integrinas, direcionando as células para sítios anatômicos específicos. Quando as quimiocinas se ligam à proteína G, elas desencadeiam e ativam uma sinalização em cascata, que faz os leucócitos aderirem a sítios específicos nos vasos sanguíneos e extravasarem para o tecido. Combinações específicas de quimiocinas, receptores de quimiocinas e moléculas de adesão formam, segundo essa teoria, um código que determina a destinação e migração de grupos de leucócitos (Luster, 1998; Murphy, 2001; Liotta, 2001; Zlotnik, 2004 e Kulbe et al. 2004). 


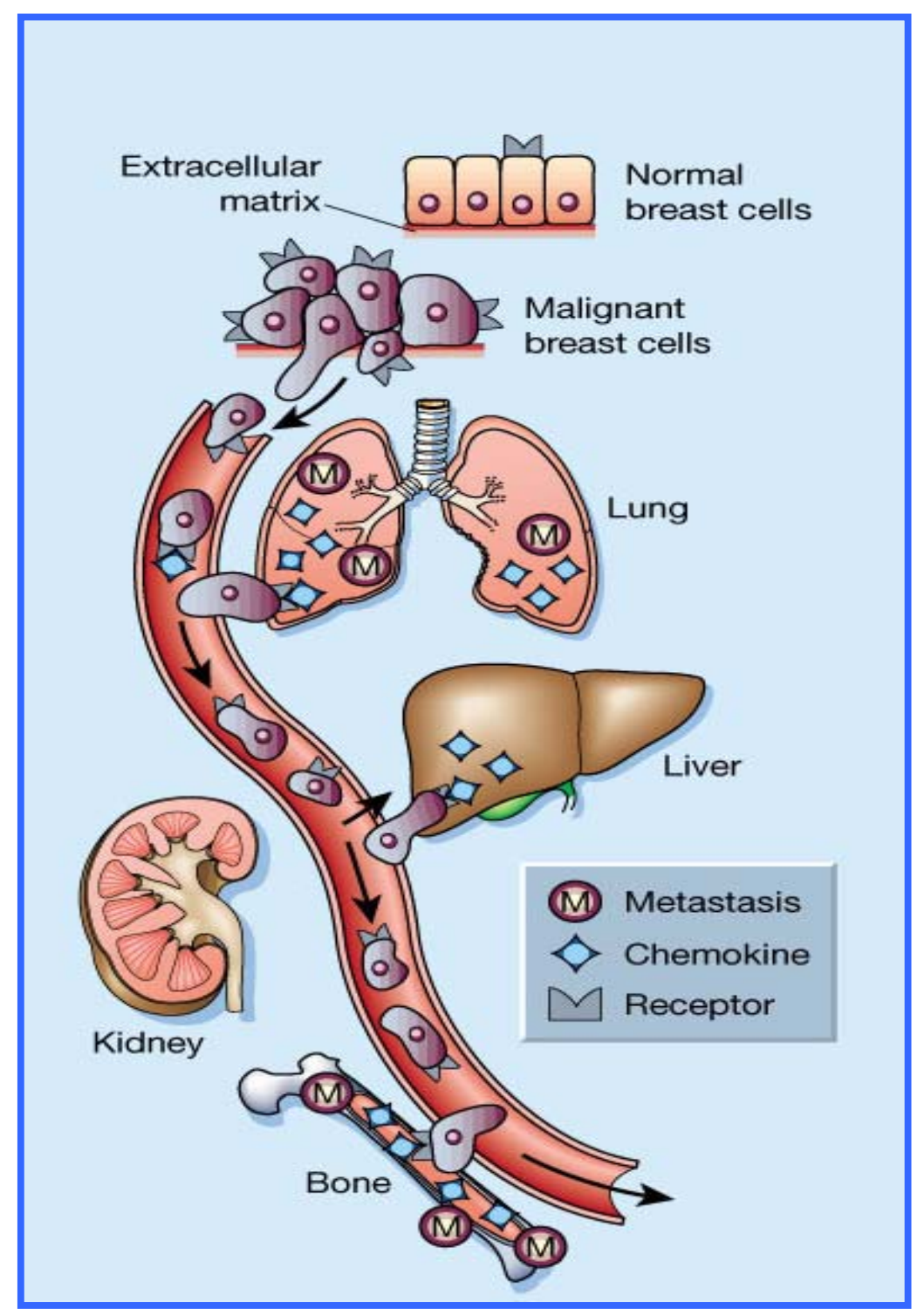

Figura 1 - Esquema ilustrativo de possíveis alvos de metástase em câncer de mama.

Comparado com o epitélio normal, o tecido maligno é enriquecido de receptores de quimiocinas na sua superfície como, por exemplo, CXCR4. Os ligantes de quimiocinas (como CXCL12 ou SDF-1) têm capacidade de reconhecer estes receptores e são liberados em altas quantidades somente em certos órgãos, como na medula óssea, fígado e pulmão. Outros órgãos, como o rim, pele ou cérebro, contém uma pequena quantidade dos ligantes de quimiocinas. As células de câncer primário de mama invadem a base da matriz extracelular, a circulação sanguínea e o sistema linfático. Quando as células de tumor de mama passam através de órgãos com grande quantidade de quimiocinas são atraídos da circulação e entram nestes órgãos. Então a distribuição final das metástases reflete a abundância relativa destas quimiocinas nos diferentes órgãos. (Liotta, 2001) 
Existem várias evidências na literatura que sugerem que este mecanismo de quimioatração de leucócitos também possa ser aplicado às células tumorais. Recentemente, Müller et al. (2001), realizaram um importante estudo onde foram examinados todos os receptores de quimiocinas conhecidos em sete diferentes linhagens tumorais mamárias para determinar se a interação de quimiocinas e receptores poderia estar envolvida no processo metastático. Verificou-se que os receptores de quimiocina 4 (CXCR4) e CCR7 estavam significantemente aumentados nas linhagens de câncer de mama em comparação com linhagens de células epiteliais mamárias normais.

Neste mesmo estudo, foram realizadas análises de citometria de fluxo que confirmaram a forte expressão de CXCR4 na superfície celular nas linhagens de tumor de mama (de 82,33 a 97,98\%). A expressão quantitativa dos mRNA de CXCR4 e CCR7 mostrou-se significantemente aumentada nos tumores primários de mama em comparação com o tecido mamário glandular normal ( $p<0,05$ e $p<0,005$, respectivamente). Foi confirmada a expressão da proteína CXCR4 in vivo, por imunohistoquímica, verificando que havia alta expressão de CXCR4 nos carcinomas invasivos ductais e que, em contrapartida, as células de tecido ductal mamário normal não expressavam este receptor.

Esses autores também observaram uma alta expressão do ligante de CXCR4, CXCL12, em linfonodos, pulmão, fígado e medula óssea, órgãos sabidamente alvos das metástases do câncer de mama. Os ligantes de CCR7, CCL21/6Ckine e CCL19/MIP-3ßb estavam abundantemente expressos em linfonodos. Observaram ainda que a ativação de células de 
câncer mamário com CXCL12 ou CCL21 desencadeava quimiotaxia e invasão tecidual in vitro, e que os extratos de órgãos alvos das metástases exerciam atividade quimiotática para as células de câncer mamário. Esse efeito quimiotático podia, por sua vez, ser neutralizado com anticorpos.

Finalmente, camundongos imunodeficientes, implantados com células MDA-MB 231 e submetidos a um tratamento com anticorpos anti CXCR4, apresentaram supressão de metástases para o pulmão entre 73 a $82 \%(p<0,001)$, e o número de metástases para os linfonodos foi reduzido, somente $38 \%$ tiveram metástases e em tamanho menor. Todos os camundongos não tratados tiveram metástases em linfonodos. Os autores concluíram que CXCR4, CCR7 e seus ligantes são quimiocinas reguladoras das metástases em câncer de mama (Müller et al. 2001).

Vários outros autores abordaram o papel dessas quimiocinas em cânceres e linhagens transformadas. Bachelder et al. (2002), indicaram que VEGF produzido pelas células de carcinoma de mama é um fator crítico para a sua invasão, e que o receptor de quimiocina CXCR4 pode mediar à migração destas células até CXCL12. Kijima et al. (2002), verificaram a expressão do mRNA do receptor de quimiocina CXCR4 em 10 linhagens celulares de câncer de pequenas células do pulmão pelo ensaio de proteção a ribonuclease (RPA) e demonstraram, por ensaios de adesão e migração, que o receptor está ativo nestas células e pode estar envolvido na patogênese deste tipo de tumor.

Em 2001, Geminder et al. observaram por RT-PCR que linhagens celulares de neuroblastoma apresentavam alta expressão de CXCR4 pela técnica de RT-PCR, além disso, verificaram por ensaios de migração e 
adesão que estas células são quimioatraídas por CXCL12, sugerindo que as células de neuroblastomas utilizem a interação CXCR4/CXCL12 no processo de metástase. Burguer et al. (1999), fizeram um trabalho semelhante com cultura de células leucêmicas de pacientes com leucemia linfocítica e observaram por RT-PCR que elas apresentam alta expressão de CXCR4 e por ensaios de quimioatração verificaram que CXCL12 induz sua quimioatração, sendo importante na migração destas células para células de estroma de medula óssea. Taichman et al. (2002), verificaram por ensaios de migração transendotelial, adesão e invasão que a interação entre CXCR4 e CXCL12 é importante na migração de células neoplásicas prostáticas para os ossos. Bertolini et al. (2002), verificaram em cultura de células de linfomas não-Hodgkins, que a neutralização de CXCR4 promove a inibição da migração transendotelial e estromal, aumento da freqüência de apoptose, redução da proliferação celular e inibição da formação de pseudopoidia em co-cultura com células estromais. Finalmente, os autores sugerem que esta neutralização poderia ser uma nova terapêutica para este tipo de câncer.

Schrader et al. (2002), realizaram um "screening" dos principais receptores de quimiocinas associados ao câncer, pela técnica de RT-PCR, em amostras de tumores de 10 pacientes com câncer de rim e observaram uma superexpressão de CXCR4. Além disso, realizaram um CDNAarray de linhagens de câncer de rim, tratadas e não tratadas com CXCL12, e observaram que muitos dos genes estimulados após tratamento estão envolvidos na regulação do ciclo celular e apoptose.

Scotton et al. (2001), em um trabalho envolvendo 10 tumores de células epiteliais humanas de ovário e verificaram pela técnica de ensaio de 
proteção a ribonuclease (RPA), que as amostras utilizadas eram CXCR4 positivas, e, por ensaios de migração sugeriram que a interação CXCR4CXCL12, forma um gradiente que influencia as rotas da migração das células metastáticas de tumor de ovário. Em outro trabalho também sobre quimiocinas em câncer de ovário, Scotton et al. (2002), verificaram que a quimiocina CXCL12 tem múltiplos efeitos biológicos no câncer de ovário, estimulando a migração celular e a invasão da matriz extracelular, assim como também estimula a síntese de DNA e o crescimento do tumor.

A importância de CXCR4 também foi explorada em câncer de mama através da técnica de SAGE (análise seriada da expressão gênica) onde os autores deste trabalho observaram alta expressão de CXCR4 em tumores de mama invasivos, quando comparados com tecidos normais (Porter et al. 2001).

Outro receptor importante parece ser o receptor de quimiocina CCR7. Hopken et al. (2002), estudaram a expressão de vários receptores de quimiocinas através da técnica de RPA em tumores de pacientes com linfoma não-Hodgkin, e verificaram que 30 das 36 amostras eram positivas para CXCR4 e que 28 das 36 amostras eram positivas também para CCR7. O aumento da expressão de CCR7 associado com maior grau de disseminação de células neoplásicas para órgãos linfóides foi outro achado desse trabalho. Till et al. (2002), verificaram que CCR7 e $\alpha 4$ integrina são importantes na migração de células de leucemia linfocítica para os linfonodos. Ainda nesse estudo, eles também encontraram maior expressão de CCR7 em pacientes com linfadenopatia, sugerindo a importância desta quimiocina como marcador de metástases para os linfonodos. O mesmo foi 
sugerido em câncer gástrico por Mashino et al. (2002), que associaram aumento de expressão de CCR7 (positiva em 42 de 64 fragmentos tumorais), pelo método de RT-PCR com presença e metástase linfonodal e de invasão linfática em carcinomas gástricos ( $p<0,001$, análise univariada). No trabalho de Takanami et al. (2003), foi realizada a investigação da expressão de CCR7 em 71 pacientes com câncer de pulmão não-pequenas células por RT-PCR e imuhistoquímica. A expressão de CCR7 e CXCR4 foi significantemente associada com metástases linfonodais, estágio e invasão linfática. O mRNA de CCR7 foi expresso em 45/71 casos, destes, 26 tinham comprometimento linfonodal $(\mathrm{pN}+)$, enquanto somente $3 / 26$ casos, sem a expressão do mRNA de CCR7, eram pN+. A expressão do mRNA de CCR7, demonstrou ser um fator preditivo independente para metástases linfonodais, por análise multivariada $(p=0,0117)$.

Existem outros estudos interessantes na literatura, mais semelhantes com nosso trabalho, como o de Delilbasi et al. (2004), que observaram a expressão de CXCR4 em carcimomas de língua por imunohistoquímica e os de Uchida et al. (2003 e 2004), que estudaram carcinomas orais escamosos e associam metástases linfonodais ao receptor CXCR4, porém, este trabalho foi realizado com um número pequeno de amostra de pacientes $(n=18)$ e algumas linhagens celulares. Em tumores de cabeça e pescoço Wang et al. publicaram em 2004 e 2005 dois artigos sobre a expressão dos receptores CCR6 e CCR7 em linhagens celulares de pacientes portadores de tumores de cabeça e pescoço. O mesmo grupo do trabalho anteriormente citado de Miller et al. publicou em 2006, outro estudo, 
envolvendo linhagens de tumores de cabeça e pescoço e verificaram a expressão dos receptores CXCR4, CXCR5 e CCR7.

Esses trabalhos em conjunto, reforçam a idéia de que as quimiocinas sejam importantes no processo de metástase. No câncer de cabeça e pescoço, seu estudo ganha importância em virtude de muitos pacientes apresentarem recidiva loco-regional, geralmente a partir de metástases linfonodais, o que piora muito o prognóstico desses doentes. Como a maior parte dos trabalhos estuda somente CXCR4 ou CCR7, nós resolvemos expandir este estudo, analisando a expressão destes e mais alguns receptores (CXCR2, CXCR3, CXCR5, CX $\left.{ }_{3} \mathrm{CR} 1\right)$ neste tipo de tumor. Nosso propósito neste trabalho foi o de estudar, em câncer epidermóide de cabeça e pescoço (HNSCC), a expressão dos receptores de quimiocinas e seus ligantes, em tumores primários, mucosa adjacente, linfonodos comprometidos e linfonodos sem comprometimento. Iniciamos o trabalho verificando quais receptores de quimiocinas eram mais expressos pela técnica de RPA, em seguida, por RT-PCR em tempo real, verificamos a expressão de quimiocinas ligantes mais conhecidas e realizamos a análise estatística para correlação desses dados com as características clínicopatológicas dos pacientes além da análise de sobrevida global e sobrevida livre de doença. 


\section{Objetivos}




\section{2- Objetivos}

\section{1- Objetivo geral e primário:}

Correlacionar os receptores de quimiocinas e seus ligantes, com a presença de acometimento linfonodal e outros parâmetros anátomo-patológicos em câncer epidermóide de cabeça e pescoço.

\section{2- Objetivos específicos:}

1-Verificar quais receptores de quimiocinas: CXCR1, CXCR2, CXCR3, CXCR4, CXCR5, CCR7 e CX 3 CR1, são expressos em câncer epidermóide de cabeça e pescoço, mucosa adjacente e linfonodos comprometidos, pela técnica do RPA.

2-Determinar pela técnica de RT-PCR em tempo real, a expressão das quimiocinas em carcinoma epidermóide de cabeça e pescoço, mucosa adjacente e linfonodos comprometidos.

3-Comparar a expressão dos marcadores acima mencionados entre tumores e linfonodos de pacientes com comprometimento lindfonodal $(\mathrm{pN}+)$ e sem comprometimento (pN0) e mucosa adjacente correlacionando-os estatisticamente com dados clínico-patológicos, sobrevida global e sobrevida livre de doença. 


\section{Métodos}




\section{3- Métodos}

\section{1- Casuística}

Neste trabalho, somente foram elegíveis para a pesquisa pacientes com carcinoma epidermóide de cabeça e pescoço (HNSCC), com indicação cirúrgica independente deste projeto. Amostras de fragmentos de tecidos de 99 pacientes com câncer epidermóide de cabeça e pescoço, submetidos à cirurgia terapêutica no grupo de Cirurgia de Cabeça e Pescoço do Hospital Heliópolis e dos linfonodos regionais macroscopicamente comprometidos ou normais que puderam ser extraídos durante a cirurgia, foram coletados prospectivamente pelo Dr. Fernando Walder, atualmente do departamento de otorrinolaringologia, Serviço de cirurgia de cabeça e pescoço da Unifesp e pelo Dr. Carlos N. Lenh, do Hospital Heliópolis (tabela 1). As amostras foram colhidas entre dezembro de 1999 e novembro de 2004, tendo mediana de seguimento de 23,67 meses. Todos os pacientes foram avisados dos objetivos da pesquisa e o material coletado só depois da obtenção do consentimento informado e após assegurar material suficiente para o andamento dos exames de rotina do paciente. Este trabalho tem a aprovação do comitê de ética da instituição em que foi realizado CAPPesq sob o número 041/03.

As amostras de tecido coletadas durante o ato cirúrgico, foram dissecadas a fresco, imediatamente congeladas em nitrogênio líquido e posteriormente encaminhadas para o laboratório de Oncologia Experimental da Faculdade de Medicina da Universidade de São Paulo. 
Os tumores foram confirmados por patologista e suas margens (mucosa adjacente), foram classificadas como livres. Em seguida foram classificados conforme o "American Joint Commitee on Cancer" 5. Edição. Basicamente, esta classificação leva em conta a disseminação anatômica dos tumores a partir de três componentes:

- Tamanho do tumor primário, designado pela letra T;

- Linfonodos regionais, designados pela letra $\mathrm{N}$;

Pacientes que receberam quimioterapia e/ou radioterapia prévia foram excluídos do nosso estudo. Nenhum dos pacientes apresentou metástases à distância.

Os desfechos estudados foram: correlação dos marcadores encontrados com parâmetros clínico-patológicos, tais como tamanho do tumor, e em especial correlação com presença ou não de metástases linfonodais ( $\mathrm{pN}+$ ou $\mathrm{pN} 0$ ). Além disso, foram coletados os dados de sobrevida livre de doença e sobrevida total. 
Tabela 1 - Características clínico-patológicas dos pacientes portadores de HNSCC, submetidos à cirurgia terapêutica no Hospital Heliópolis, utilizados na determinação da expressão dos mRNAs dos receptores de quimiocinas por RPA.

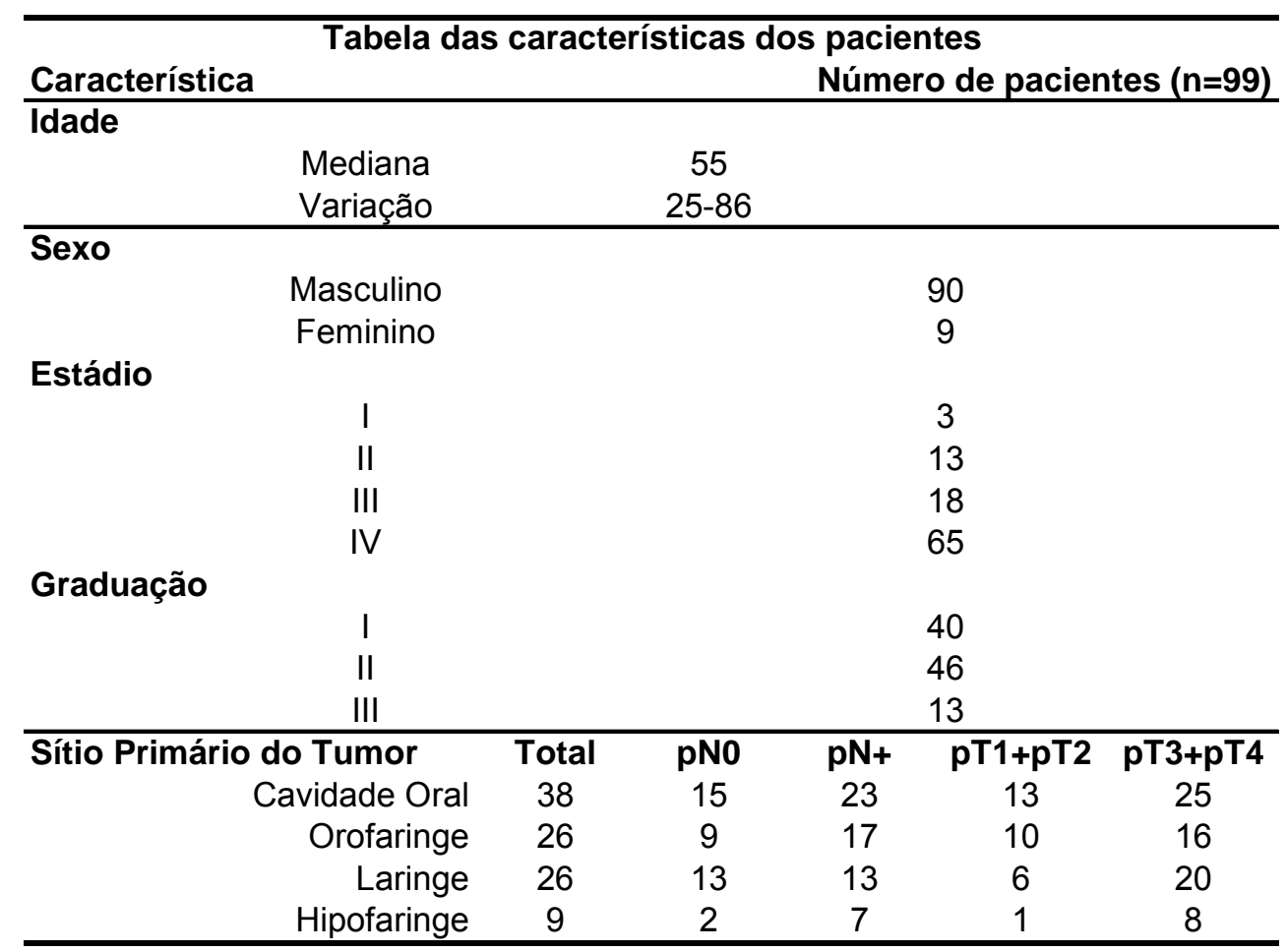

\section{2- Extração do RNA total}

As amostras dos pacientes foram pulverizadas com o aparelho Termovax (Technolab Coporation) e aproximadamente $100 \mathrm{mg}$ foi transferido para um tubo de 2,0 mL, DNAse/RNAse free. O RNA total das amostras foi extraído adicionando-se $1 \mathrm{~mL}$ do reagente TRIZOL (Invitrogen, Life Technologies, CA, USA), uma solução monofásica de fenol e Isoticianato de Guanidina, uma otimização do método de extração de RNA desenvolvido por Chomczinski e Sacchi, 1987. 
As amostras foram homogeneizadas com um vortex, incubadas em temperatura ambiente por 5 minutos, centrifugadas por 15 minutos a 12.000 g e o sobrenadante transferido para um novo tubo, ao qual foram adicionados $200 \mu \mathrm{L}$ de clorofórmio (Merck, AL). Em seguida, a amostra foi homogeneizada em vortex, incubada por 10 minutos em temperatura ambiente e novamente centrifugada a $12.000 \mathrm{~g}$ por 15 minutos. O sobrenadante foi retirado com cuidado, evitando-se a interfase, transferido para um novo tubo ao qual foram adicionados $500 \mu \mathrm{L}$ de álcool Isopropílico (Merck, $A L$ ) e homogeneizado por inversão. A amostra foi incubada por uma noite em freezer $\mathrm{a}-20^{\circ} \mathrm{C}$.

Após centrifugação por 10 minutos a $12.000 \mathrm{~g}$, o sobrenadante foi desprezado e o precipitado lavado com $1 \mathrm{~mL}$ de Etanol $75 \%$ em $\mathrm{H}_{2} \mathrm{O}$ DEPC (ambos Merck, AL). A amostra foi submetida a uma nova centrifugação por 5 minutos a $7.500 \mathrm{~g} \mathrm{a} 4^{\circ} \mathrm{C}$, o sobrenadante desprezado e o preciptado de RNA foi seco a temperatura ambiente e ressuspendido em $\mathrm{H}_{2} \mathrm{O}$ DEPC.

A concentração do RNA total de cada amostra foi determinada por leitura em espectofotômetro em comprimento de onda de $260 \mathrm{~nm}$. A integridade da amostra foi verificada em gel de agarose $1 \%$ corado com Brometo de Etídio.

\section{3- Ensaio de proteção a Ribonuclease (RPA)}

O ensaio de Proteção à Ribonuclease foi realizado usando o kit hCR-6 RiboQuant ${ }^{\mathrm{TM}}$ Multi Probe Rnase Protection Assay (Pharmigen, CA, 
USA) que, basicamente, consiste na síntese de RNA antisenso, marcado com fósforo radioativo que servirá como sonda para a detecção de mRNA específico, que neste caso correspondem aos receptores de quimiocinas. Essas sondas foram sintetizadas em um sistema de transcrição in vitro utilizando como molde fragmentos das sequências de DNAs complementares aos mRNA de interesse, cada qual com um tamanho distinto em pares de base (CXCR1 sonda 390 e sonda protegida 364, CXCR2 sonda 350 e sonda protegida 324 , CXCR3 sonda 315 e sonda protegida 287, CXCR4 sonda 285 e sonda protegida 257, CXCR5 (BLR1) sonda 232 e sonda protegida 204 , CCR7 sonda 208 e sonda protegida 179 , $\mathrm{CX}_{3} \mathrm{CR} 1$ (V28) sonda 189 e sonda protegida 161, L32 sonda 141 e sonda protegida 113, GAPDH sonda 124 e sonda protegida 96) clonados em um plasmídeo contendo o sítio de ligação T7 RNA polimerase. O conjunto das sondas foi hibridizado ao RNA total da amostra de interesse, sendo essa reação seguida da ação de uma RNAse que degrada todos os RNAs de fita simples, mantendo intactos aqueles que ficaram ligados às seqüências complementares. Esses RNAs dupla fita, protegidos da ação da RNAse, foram purificados e aplicados em gel desnaturante de poliacrilamida. Um filme de raios-X foi exposto a esse gel e o sinal gerado foi quantificado em um densitômetro Image Máster VDS com o programa ImageMaster VDS software, versão 2.0 - GE Healthcare Biociences antiga Amershan Biociences, ST. Giles, UK. 


\subsection{1- Síntese das sondas}

Para a síntese das sondas foram adicionados em tubo de $1,5 \mathrm{~mL}$ os

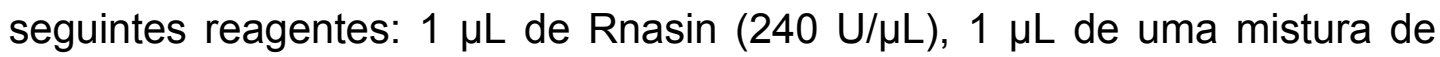
nucleotídeos GACU [CTP, ATP, GTP $(2,5 \mathrm{mM})$ e UTP $(61 \mu \mathrm{M})], 2 \mu \mathrm{L}$ de DTT $100 \mathrm{mM}, 4 \mu \mathrm{L}$ de tampão de transcrição $5 \mathrm{X}, 1 \mu \mathrm{L}$ da mistura de moldes para síntese dos RNAs de interesse, $10 \mu \mathrm{L}$ de $\left[\alpha-{ }^{32} \mathrm{P}\right] \mathrm{UTP}$ (GE Healthcare Biociences antiga Amershan Biociences, ST. Giles, RU), $1 \mu \mathrm{L}$ de RNA polimerase T7 $(20 \mathrm{U} / \mu \mathrm{L})$, os reagentes foram homogeneizados e incubados a $37^{\circ} \mathrm{C}$ por 1 hora. Neste tubo, foram adicionados $26 \mu \mathrm{L}$ de EDTA $20 \mathrm{mM}, 25$ $\mu \mathrm{L}$ de Fenol saturado em Tris-HCl (Merck, $\mathrm{AL}$ ), $25 \mu \mathrm{L}$ de Clorofórmio: Álcool Isoamílico (50:1, ambos Merck, AL), $2 \mu \mathrm{L}$ de RNAt de levedura $(2 \mathrm{mg} / \mathrm{mL})$, seguido de uma agitação vigorosa em um vortex e de uma centrifugação por 5 minutos a temperatura ambiente em velocidade máxima. A fase aquosa superficial foi transferida para um novo tubo de $1,5 \mathrm{~mL}$ no qual foram adicionados $50 \mu \mathrm{L}$ de Clorofórmio: Álcool Isoamílico (50:1). Após homogeneização e centrifugação de 2 minutos em temperatura ambiente, a fase aquosa foi transferida para um novo tubo de $1,5 \mathrm{~mL}$ ao qual foram adicionados $50 \mu \mathrm{L}$ de acetato de amônio $4 \mathrm{M}$ e $250 \mu \mathrm{L}$ de etanol $100 \%$ gelado. A mistura foi homogeneizada por inversão e incubada por 30 minutos a $-70^{\circ} \mathrm{C}$. Os tubos foram centrifugados por mais 15 minutos a $4^{\circ} \mathrm{C}$ e o sobrenadante cuidadosamente retirado. Ao precipitado foram adicionados $100 \mu \mathrm{L}$ de etanol $90 \%$ gelado e o material novamente centrifugado por 5 minutos a $4^{\circ} \mathrm{C}$. O sobrenadante foi removido e o precipitado permaneceu a temperatura ambiente de 5 a 10 minutos para secar. O precipitado foi 
ressuspendido em $50 \mu$ l de tampão de hibridização, e uma alíquota de $1 \mu \mathrm{l}$ foi retirada em duplicata para quantificar a marcação em um contador de radiação beta. As sondas foram mantidas a $-20^{\circ} \mathrm{C}$ e puderam ser usadas por até 48 horas.

\subsection{2- Preparação do RNA e Hibridização}

Para os ensaios de hibridização foram necessários $10 \mu \mathrm{g}$ do RNA total de cada uma das amostras de interesse que foram aliquotadas cada qual em um tubo de $1,5 \mathrm{~mL}$ sendo utilizado também um tubo contendo RNAt de levedura como controle negativo da reação. Como controle positivo do ensaio utilizamos $2 \mu \mathrm{g}$ do RNA controle da empresa Pharmigen.

As amostras de RNA foram secas e ressuspendidas em $8 \mu \mathrm{L}$ do tampão de hibridização. As sondas foram diluídas na concentração de 2,1 X $10^{5} \mathrm{cpm} / \mu \mathrm{l}$, conforme as indicações do fabricante. A cada amostra de RNA foram adicionados $2 \mu \mathrm{L}$ de sonda diluída e homogeneizados. Com a finalidade de se evitar a evaporação foram adicionados $50 \mu \mathrm{L}$ de óleo mineral autoclavado em cada tubo. Os tubos foram aquecidos a $90^{\circ} \mathrm{C}$ e então submetidos a uma lenta redução de temperatura até $56^{\circ} \mathrm{C}$ por 12 a 16 horas.

\subsection{3- Tratamentos com RNAse}

Após este período, as amostras foram submetidas a uma gradativa redução da temperatura para $37^{\circ} \mathrm{C}$ por 15 minutos e foram adicionados, sob o óleo mineral, $100 \mu \mathrm{L}$ de uma solução RNAse [2,5 mL de tampão RNAse A 
+ T1 (A: 80ng/ $\mu \mathrm{L} ; \mathrm{T} 1: 250 \mathrm{U} / \mu \mathrm{L}$ ) volume para 20 amostras] e os tubos foram submetidos a uma centrifugação por 45 minutos a $30^{\circ} \mathrm{C}$.

Em um novo tubo de $1,5 \mathrm{~mL}$, foram adicionados $18 \mu \mathrm{L}$ de uma solução de proteinase $\mathrm{K}(390 \mu \mathrm{L}$ de tampão de proteinase $\mathrm{K}, 30 \mu \mathrm{L}$ de proteinase $\mathrm{K} 10 \mathrm{mg} / \mathrm{mL}, 30 \mu \mathrm{L}$ de RNAt de levedura, volume para 20 amostras). A fase inferior da reação de RNAse foi transferida para o tubo a solução de proteinase $\mathrm{K}$, homogeneizada em vortex e centrifugada. A mistura foi incubada por 15 minutos a $37^{\circ} \mathrm{C}$, e após este período, foram adicionados $65 \mu \mathrm{L}$ de Fenol saturado em Tris e $65 \mu \mathrm{L}$ de Clorofórmio:Álcool Isoamílico (50:1), e após homogeneização vigorosa, foi centrifugado por 5 minutos a temperatura ambiente a $12.000 \mathrm{~g}$ de centrifugação. A fase aquosa foi cuidadosamente transferida para um novo tubo ao qual foram adicionados $120 \mu \mathrm{L}$ de acetato de amônio $4 \mathrm{M}$ e $650 \mu \mathrm{L}$ de etanol 100\% gelado. Após homogeneização por inversão, o material foi incubado por 30 minutos a $-70^{\circ} \mathrm{C}$ e centrifugado por 15 minutos a $4^{\circ} \mathrm{C}$. O sobrenadante foi removido e o precipitado lavado com $100 \mu \mathrm{L}$ de etanol $90 \%$ gelado. Depois de uma nova centrifugação de 5 minutos a $4^{\circ} \mathrm{C}$, o sobrenadante foi então desprezado e o precipitado seco à temperatura ambiente. Antes de aplicar as amostras no gel, o material foi ressuspendido em $5 \mu \mathrm{L}$ de tampão de amostra $1 \mathrm{X}$ com o auxílio de um vortex e mantidos por 3 minutos a $90^{\circ} \mathrm{C}$ sendo imediatamente resfriados e mantidos em gelo até a aplicação. 


\subsection{4- Resolução em gel das sondas protegidas}

A eletroforese foi realizada em gel de poliacrilamida de aproximadamente $40 \mathrm{~cm}$ de altura por $0,4 \mathrm{~mm}$ de espessura. As placas de vidro foram siliconizadas, o gel foi feito com uma concentração de acrilamida final de 5\% utilizando-se $100 \mathrm{~mL}$ de solução de acrilamida (19:1 acrilamida/bis): $12 \mathrm{~mL}$ de acrilamida 40\%, 12,5 mL de bis-acrilamida $2 \%, 48 \mathrm{~g}$ de uréia (ambas marca Invitrogen, Life Technologies, CA, EUA), $10 \mathrm{~mL}$ de TBE (Tris, ácido bórico e ácido Ethylenodiaminotetracético) 10X, completando com água até 100 $\mathrm{mL}, 604 \mu \mathrm{L}$ de persulfato de amônio $10 \%$ e $80,5 \mu \mathrm{L}$ de TEMED. A solução foi imediatamente aplicada e, após polimerização, foi realizada uma pré-corrida em tampão TBE $0,5 X$ a 40 volts por 45 minutos. Após este período, aproximadamente $2000 \mathrm{cpm}$ da sonda e as amostras de RNA protegido foram aplicadas no gel e migraram até que o corante bromofenol blue alcançasse 30 $\mathrm{cm}$, com uma força constante de 50 volts. O aparato foi desmontado e um papel filtro 3M colocado foi sobre o gel para secagem. Em seguida o gel foi envolvido em filme plástico e transferido para o secador de gel, onde permaneceu por 1 hora a temperatura de $-80^{\circ} \mathrm{C}$. Posteriormente, um filme de raios-X Hyperfilm (GE Healthcare, CA, USA) foi exposto a esse gel em um chassi com intensificador de imagem e mantido $\mathrm{a}-70^{\circ} \mathrm{C}$ de 2 a 4 dias.

A identificação das bandas correspondentes aos RNAs protegidos foi possível através da plotagem das distâncias entre as bandas em papel gráfico de semi-log, conforme instrução do fabricante. As bandas impressionadas no autoradiograma foram quantificadas em um densitômetro pelo programa ImageMaster VDS software e expressas segundo o conteúdo de L32 presente na mesma amostra. 


\section{4- RT-PCR em Tempo Real}

\subsection{1- Síntese de cDNA}

Inicialmente, foi feita a preparação da primeira fita de cDNA a partir de RNA total não tratado, uma reação de $40 \mu$ totais. Utilizamos $5 \mu \mathrm{g}$ de RNA total, $200 \mathrm{ng}$ de oligonucleotídeo Randon Hexâmero e $19 \mu \mathrm{l}$ de $\mathrm{H}_{2} \mathrm{O}$. Foi realizada a incubação desta amostra por 10 minutos a uma temperatura de $70^{\circ} \mathrm{C}$, seguida de 10 minutos a temperatura ambiente. Foi preparada uma mistura contendo $8 \mu \mathrm{l}$ de tampão Super Script 10X [Tris- $\mathrm{HCl} 250 \mathrm{mM}, \mathrm{KCl}$ $376 \mathrm{mM}$ e $\mathrm{MgCl}_{2} 15 \mathrm{mM}$ ], $4 \mu \mathrm{l}$ de dNTPs $200 \mu \mathrm{M}, 2 \mu \mathrm{l}$ de Super Script III $(200 U / \mu \mathrm{l})$ e $4 \mu \mathrm{l}$ de DTT 0,1M (Invitrogen, Life Technologies, CA, EUA), esta mistura foi adicionada na amostra e foi incubada a $50^{\circ} \mathrm{C}$ por 50 minutos, seguidos de 15 minutos a $70^{\circ} \mathrm{C}$ para inativação da enzima. A concentração do cDNA foi determinada por leitura em espectofotômetro em comprimento de onda de 260nM. Os cDNAs foram posteriormente diluídos a uma concentração de $20 \mathrm{ng} / \mu \mathrm{l}$ e armazenados em freezer a temperatura de $20^{\circ} \mathrm{C}$.

Como controle da reação de síntese de cDNA foi feita uma PCR teste com oligonucleotídeos para o gene da B-actina (Tabela 2), na qual foi utilizado para cada amostra $19 \mu$ de uma mistura dos seguintes reagentes: 2 $\mu \mathrm{l}$ de tampão PCR 10X, 0,6 $\mu \mathrm{l}$ de $\mathrm{MgCl}_{2}$ 50mM, $2 \mu \mathrm{l}$ de dNTPs $2 \mathrm{mM}, 1 \mu \mathrm{l}$ de cada um dos oligonucleotídeo sense ou antisense 2mM (IDT, IA, USA), 0,3 $\mu \mathrm{l}$ de Taq Polimerase 5U/ $\mu \mathrm{l}, 12,1 \mu \mathrm{l}$ de $\mathrm{H}_{2} \mathrm{O}$, (Invitrogen, Life Technologies, 
CA, EUA) e $1 \mu$ de cDNA. Essa reação foi realizada em um termociclador Gene Amp PCR System 9700 (Applied Biosystems, CA, EUA), nas seguintes condições: $95^{\circ} \mathrm{C}$ por 5 minutos, seguidos de 35 ciclos com as seguintes temperaturas: $95^{\circ} \mathrm{C}$ por 60 segundos, $62^{\circ} \mathrm{C}$ por 60 segundos, $72^{\circ} \mathrm{C}$ por 60 segundos e uma extensão final de 10 minutos a $72^{\circ} \mathrm{C}$. O produto desta reação foi aplicado em um gel de agarose $2 \%$ para verificação dos transcritos amplificados.

\subsection{2- PCR em Tempo Real}

Inicialmente foi preparada uma mistura contendo: $2 \mu$ de tampão PCR 10X, 0,8 $\mu \mathrm{l} \mathrm{MgCl}_{2} 50 \mathrm{mM}$ e $1,6 \mu \mathrm{l}$ de dNTPs $2,5 \mathrm{mM}$ (Invitrogen, Life Technologies, CA, EUA), $2 \mu \mathrm{l}$ de cada um dos oligonucleotídeos sense ou antisense $2 \mathrm{mM}$ (Tabela 2), (IDT, IA, EUA, $1 \mu \mathrm{l}$ de Albumin Serum Bovine 100X (Promega, WI, USA), $1 \mu$ I de DMSO (Sigma, CA, EUA), 0,3 $\mu$ I de Taq Polimerase Platinum 5U/ul (Invitrogen Life Technologies, CA, EUA), 0,3 $\mu$ lde Sybr Green Nucleic Acid Gel Stain 100X (Molecular Probes, OR, EUA), e 4,0 $\mu$ de $\mathrm{H}_{2} \mathrm{O}$ Ultra Pure (Invitrogen, Life Technologies, CA, EUA). Esse procedimento foi realizado em fluxo laminar, na ausência de luz, em temperatura de $4^{\circ} \mathrm{C}$. Desta mistura foram pipetados $15 \mu \mathrm{l}$ por amostra e mais $5 \mu \mathrm{l}$ do cDNA e sempre analisando cada amostra em duplicata. Além disso, incluímos também um controle normal (cDNA pool de tecidos normais de cabeça e pescoço) e os controles negativos ou branco. As amostras foram homogeneizadas e mantidas ao abrigo da luz. A reação foi realizada e sua 
fluorescência medida no aparelho Rotor Gene (Corbett Research, AUS). O programa para a amplificação das amostras consiste em uma desnaturação inicial a $95^{\circ} \mathrm{C}$ por 5 minutos, seguidos de 40 ciclos de $95^{\circ} \mathrm{C}$ por 15 segundos para desnaturação, $62^{\circ} \mathrm{C}$ por 1 minuto para associação, $72^{\circ} \mathrm{C}$ por mais 1 minuto para extensão final e por fim uma curva de dissociação ascendente de 72 a $95^{\circ} \mathrm{C}$ com aumento de $0,2^{\circ} \mathrm{C}$ por segundo. Inicialmente fizemos curvas para padronização das condições de reação para cada gene com $200 \mathrm{ng}, 150 \mathrm{ng}, 100 \mathrm{ng}$ e $50 \mathrm{ng}$. Após a realização das curvas, foram traçadas retas, onde foi determinada a equação da reta $y=a x+b$ e em seguida foi calculada a eficiência de amplificação de cada oligonucleotídeo pela fórmula $10^{(-1 / a)}-1$. Verificamos que as eficiências de amplificação dos oligonucleotídeos genes estavam próximas de 100\% e por isso poderiam ser utilizados no experimento. A concentração de cDNA que se mostrou mais adequada aos nossos ensaios foi a de 100ng, e foi utilizada para todas as amostras e para todos os genes. Os oligonucleotídeos utilizados para este ensaio estão descritos na tabela 2:

Tabela 2 - Descrição dos Oligonucleotídeos utilizados no ensaio de PCR em tempo real.

\begin{tabular}{lcc}
\hline Oligonucleotídeos & \multicolumn{1}{c}{ Sense } & Antisense \\
\hline Beta Actina Humana & AGAAAATCTGGCACCACACC & AGAGGCGTACAGGGATAGCA \\
CXCL12 Humana & CCCGAAGCTAAAGTGGATTC & GGCAAAGTGTGCAAAACAAA \\
CCL19 Humana & GACCTCAGCCAAGATGAAGC & CGCTCACACTCACCTCACA \\
CCL21 Humana & AAGGCTGCAAGAGGACTGA & GGAGAAAGAGTGTGGCAAGG \\
CX ${ }_{3}$ CL1 Humana & TCTGCCATCTGACTGTCCTG & CATGATGCCTGGTTCTGTTG \\
\hline
\end{tabular}


Os resultados foram analisados com o auxílio do programa Rotor Gene versão 6.0 (Corbett Research, AUS) e pelo programa Excel em ambiente Windows. A detecção dos produtos foi feita pelo monitoramento do sinal fluorescente emitido pelo corante SYBR green (Molecular Probes, OR, EUA), que se intercala a dupla fita do DNA, obtido no final de cada ciclo. Os valores quantitativos $(\mathrm{Ct})$ foram obtidos a partir do ciclo limiar onde $\mathrm{o}$ aumento no sinal associado ao crescimento exponencial dos produtos de PCR começa a ser detectado. Os RNAs mensageiros das quimiocinas CXCL12, CCL19, CCL21 e $\mathrm{CX}_{3} \mathrm{CL} 1$ foram quantificados relativamente à expressão de um gene controle, Beta actina, subtraindo a média de valores do ciclo limiar $(\mathrm{Ct})$ deste gene da média do $\mathrm{Ct}$ gerado pelo gene interesse. Este valor é chamado de $\Delta \mathrm{Ct}$. Ao $\Delta \mathrm{Ct}$ obtido da amostra do gene interesse é então, subtraído o $\Delta \mathrm{Ct}$ de uma amostra que é utilizada como calibrador, no nosso caso, um tecido normal de boca (gengiva). Este valor é chamado de $\Delta \Delta$ Ct. O valor da relação que é utilizado para a análise estatística é calculado: potência de 2 elevada a $-\Delta \Delta \mathrm{Ct}\left(2^{-\Delta \Delta \mathrm{Ct}}\right)$. Este valor corresponde à expressão do mRNA do gene estudado em relação ao tecido normal.

\section{5- Correlações Estatísticas}

As expressões relativas dos RNAs mensageiros das quimiocinas estudadas foram comparadas entre as amostras tecido tumoral, mucosa adjacente e linfonodos comprometidos utilizando o teste T pareado. Para a 
comparação realizada em relação aos parâmetros clínico-patológicos utilizamos o Teste T não pareado.

Os pacientes foram categorizados como positivos ou negativos para cada quimiocina, segundo o valor da expressão relativa, se acima ou abaixo da mediana do grupo e as curvas de sobrevida livre de doença e global foram determinadas pelo método de Kaplan-Meier. Os subgrupos prognósticos foram comparados pelo teste de Log Rank.

Todos os testes estatísticos foram realizados com o auxílio do programa SPSS 10.0. Foi considerado significante $p \leq 0.05$ e marginalmente significante $p \leq 0.10$ 


\section{Resultados}




\section{4- Resultados:}

\subsection{Determinação da Expressão dos mRNA dos Receptores de Quimiocinas}

Nesta etapa do estudo avaliamos a expressão dos mRNA dos receptores de quimiocinas CXCR1 a 5, CCR7 e $\mathrm{CX}_{3} \mathrm{CR} 1$ ) em 98 fragmentos de tecido tumoral, 91 de mucosa adjacente, 26 linfonodos regionais comprometidos obtidos de pacientes portadores de Carcinoma Epidermóide de Cabeça e Pescoço pelo ensaio de RPA (kit hCR-6). A expressão dos receptores de quimiocinas foi considerada como sendo a razão entre seu valor densitométrico e da L32 correspondente (figura 2).

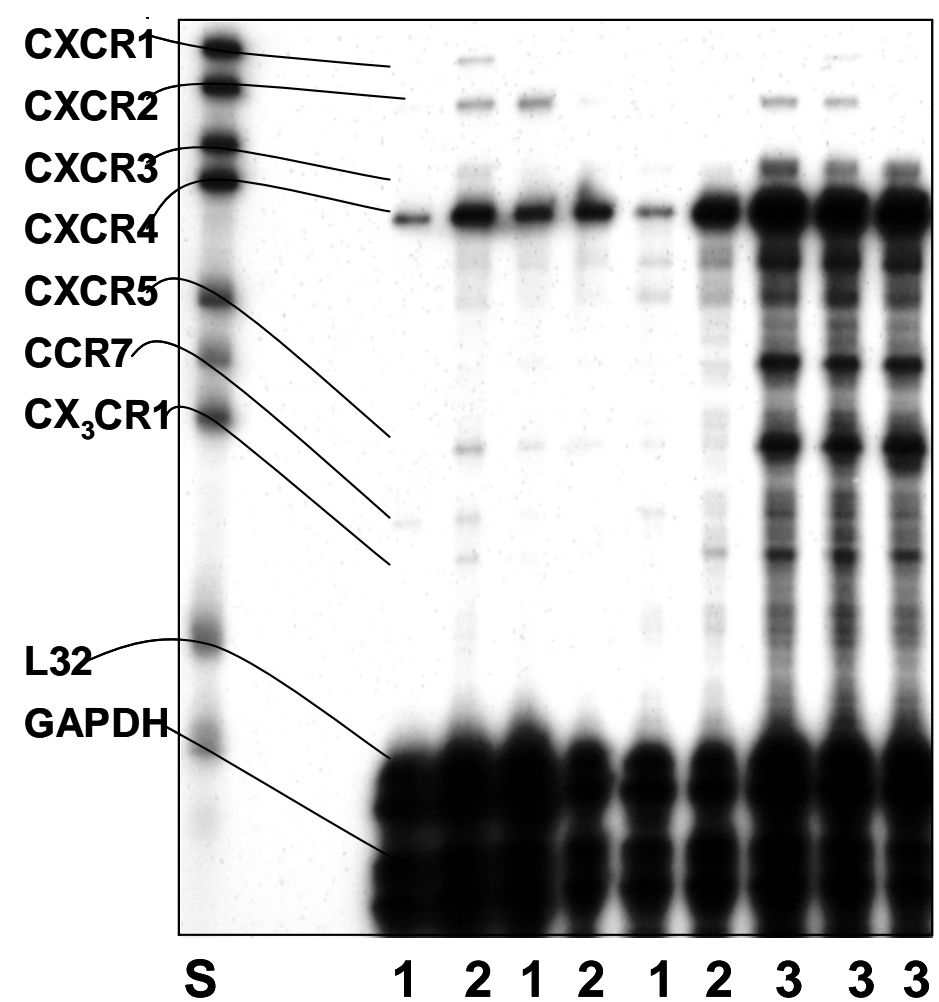

Figura 2. Autorradiograma de um ensaio representativo mostrando a expressão dos mRNA dos receptores de quimiocinas em HNSCC pelo método de RPA. O RNA total das amostras foi utilizado para verificação da expressão do mRNA conforme descrito em métodos. $S$ - sonda desprotegida, 1 - mucosa adjacente, 2- tumor, 3- linfonodo comprometido. A expressão do gene L32 foi utilizada como controles da reação. 
Entre os diversos receptores de quimiocinas estudados, observamos que existe um padrão diverso de expressão. A expressão do mRNA de CXCR1 foi observada em $57 \%$ das 98 amostras de tecido tumoral, a de CXCR2 em 60\%, CXCR3 em 53\%, CXCR4 em 100\%, CXCR5 em 41\%, CCR7 em $56 \%$ e $\mathrm{CX}_{3} \mathrm{CR} 1$ em $51 \%$ das amostras. A porcentagem de positividade de expressão desses receptores não variou muito em relação à mucosa adjacente, exceto quanto a CXCR3 expressa em $35 \%$ e a $\mathrm{CX}_{3} \mathrm{CR} 1$ em 43\% das 91 amostras estudadas (CXCR1: 54\%, CXCR2: 58\%, CXCR4: 100\%, CXCR5: 36\%, CCR7: 49,5\%).

Em uma primeira análise, comparamos a expressão dos mRNA dos receptores de quimiocinas entre os tumores e a mucosa adjacente no grupo como um todo (HNSCC, $n=89$ ). Os receptores CXCR1, CXCR3 e CXCR4 tiveram aumento de expressão significativo no tecido tumoral $(p=0,013, p=0,008$ e $p=0,025$, respectivamente, teste $T$ pareado) quando comparado à mucosa adjacente. Entretanto, em relação ao CXCR5 $(p=0,098)$ observamos apenas uma tendência a uma menor expressão no tecido tumoral, enquanto que as expressões dos demais genes não diferiram entre os grupos (CXCR2: $p=0,862$; CCR7: $p=0,401$ e $C_{2}{ }_{3} C R 1$ : $p=0,407$, Tabela 3 e Figuras 3 e 4). 
Tabela 3 - Comparação da média e desvio padrão relativos à expressão do RNA mensageiro dos receptores de quimiocinas entre tumores e mucosa adjacente, considerados entre todos os sítios tumorais estudados. São consideradas diferenças estatísticas ${ }^{*} p \leq 0,05$ e marginalmente significantes ${ }^{* *} \mathrm{p} \leq 0,1$ (teste t-pareado).

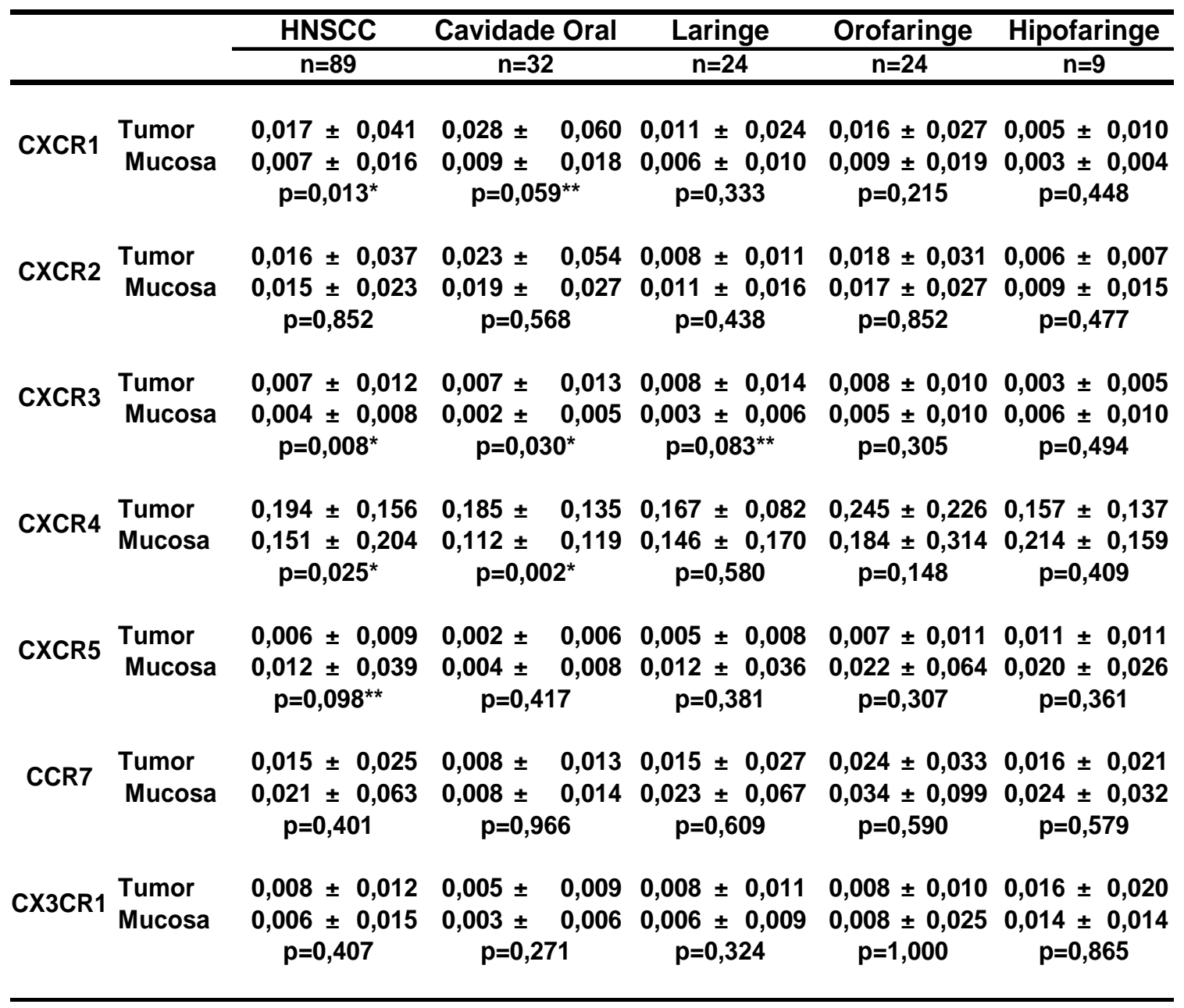



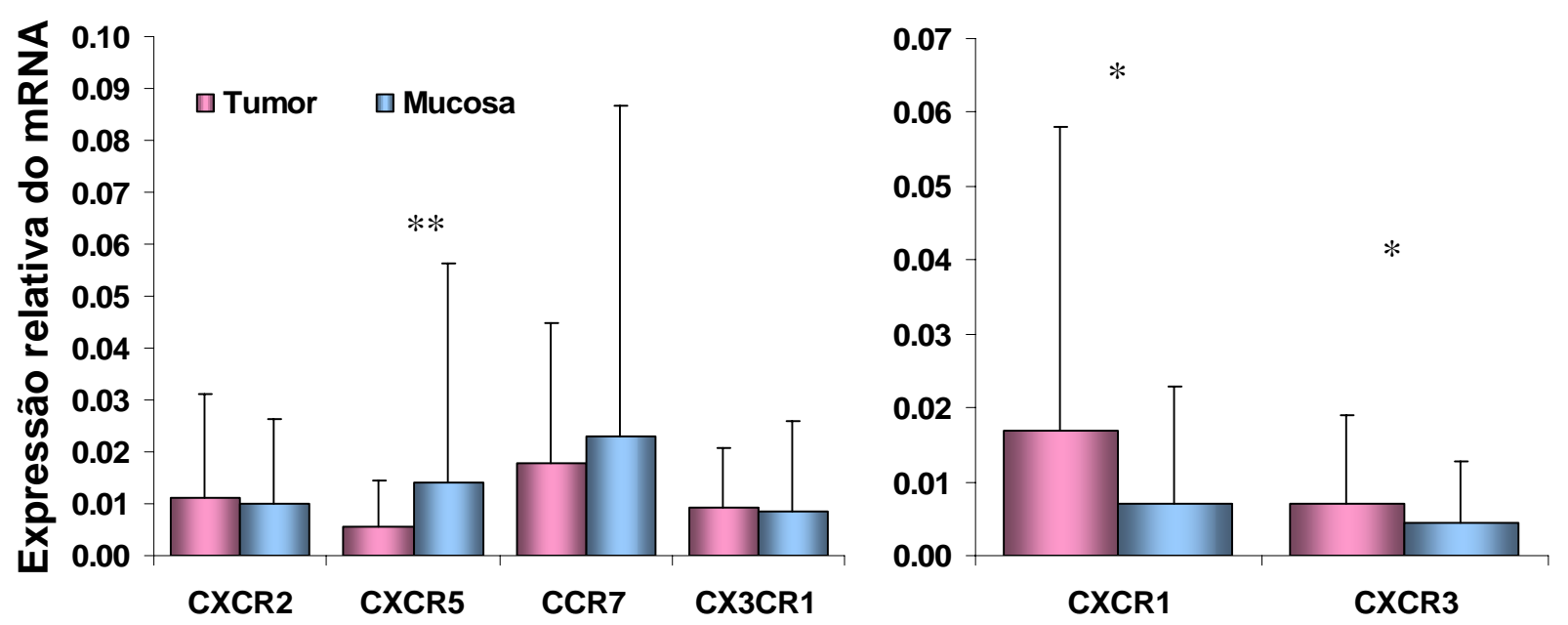

Figura 3 - Expressão dos mRNA de receptores de quimiocinas em HNSCC. Comparação da média e desvio padrão relativos à expressão de cada receptor nas amostras de tumor e mucosa adjacente $(n=98)$. *CXCR1 $p=0,013$ e CXCR3 $p=0,008$, e uma tendência a aumento de expressão no tecido normal: ${ }^{* *} \mathrm{CXCR5} p=0,098$ (teste T pareado).

Considerando-se os tumores de cavidade oral $(n=32)$, observamos um aumento significante da expressão do mRNA de CXCR4 $(p=0,002$, teste T pareado) e de $\operatorname{CXCR3}(p=0,030)$ nos tumores em relação à mucosa adjacente. Os demais receptores de quimiocinas CXCR1 $(p=0,059)$, CXCR2 $(p=0,568), \operatorname{CXCR5}(p=0,417), \operatorname{CCR} 7(p=0,966)$ e $\operatorname{CX}_{3} \operatorname{CR} 1(p=0,271)$ não apresentaram diferenças de expressão significativas entre os dois grupos (Tabela 3, Figuras 4 e 5). 


\section{CXCR4}

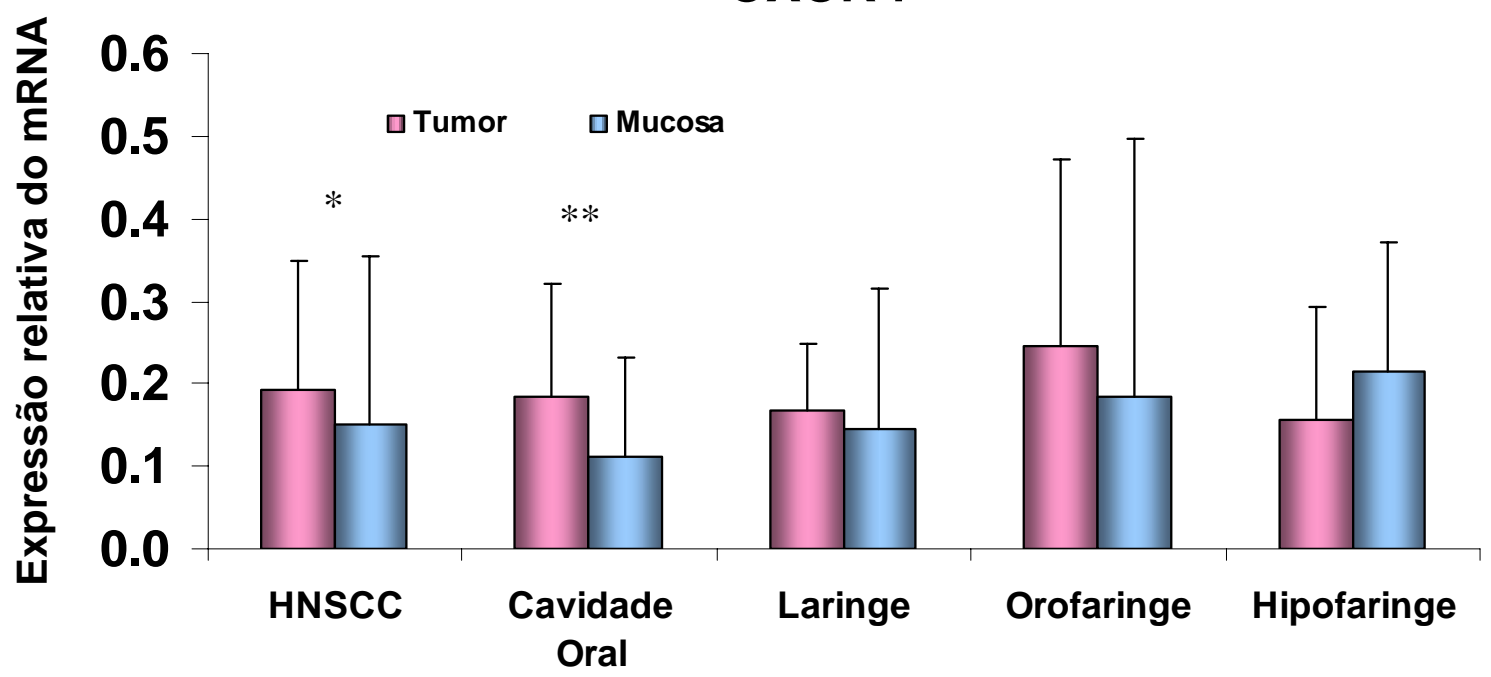

Figura 4 - Expressão do mRNA do receptor de quimiocina CXCR4, no grupo como um todo e nos sítios de carcinoma epidermóide de cabeça e pescoço. Comparação da média e desvio padrão da expressão de CXCR4 entre amostras de tumor e mucosa adjacente. HNSCC $(n=89)$ ${ }^{*} \mathrm{p}=0,025$; Cavidade Oral $(n=32){ }^{* *} \mathrm{p}=0,002$; Laringe $(n=24) \quad \mathrm{p}=0,580$; Orofaringe $(n=24) p=0,148$; Hipofaringe $(n=9) p=0,490$.

Nos tumores de laringe $(n=24)$, somente o receptor CXCR3 apresentou uma tendência a aumento de expressão nos tumores $(p=0,083)$. Considerando-se somente os tumores de orofaringe $(n=24)$ ou de hipofaringe $(n=9)$ nenhuma diferença de expressão dos receptores estudados foi encontrada (Tabela 3, Figura 4 e 5) 

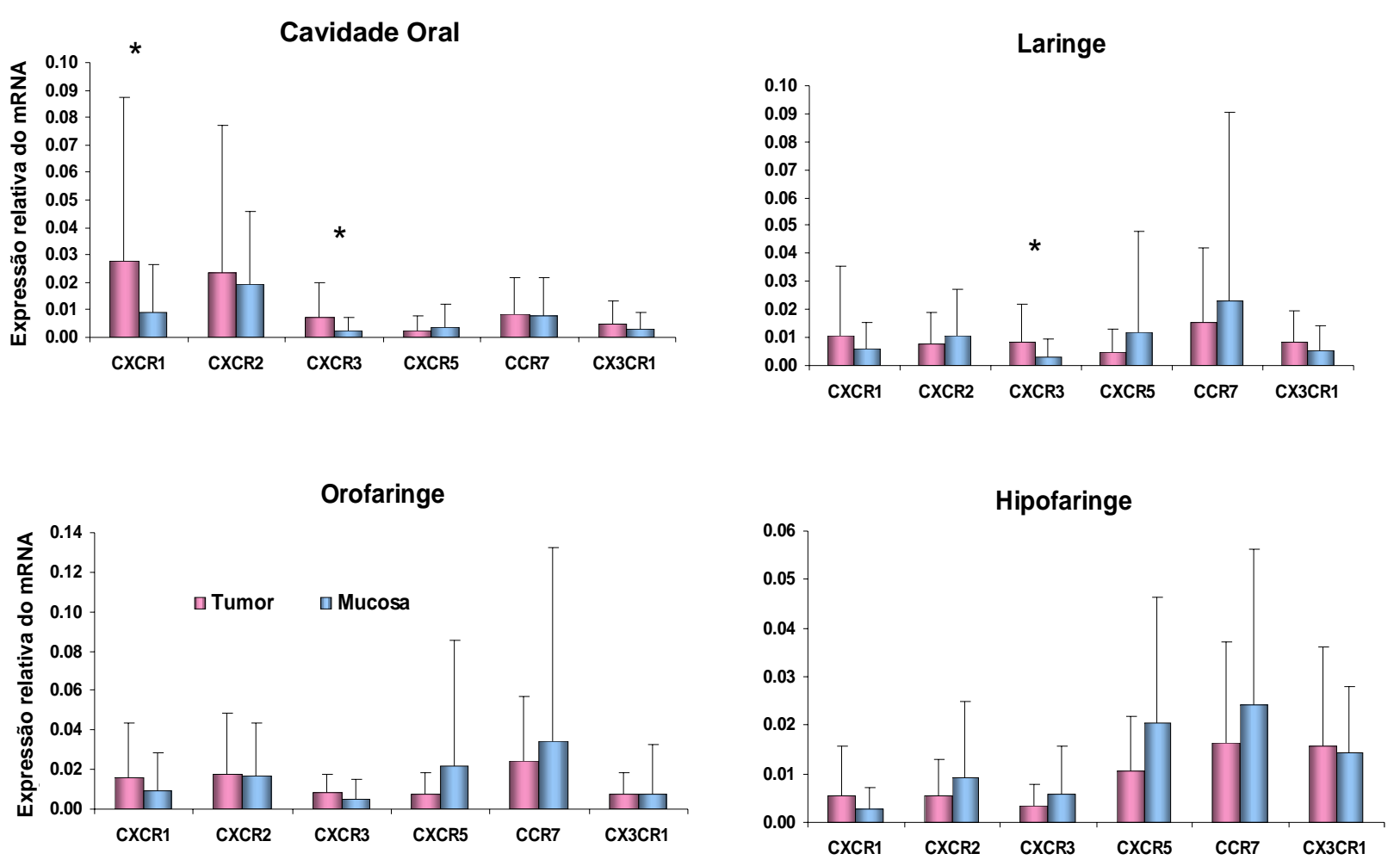

Figura 5 - Expressão dos mRNA de receptores de quimiocinas nos sítios de carcinoma epidermóide de cabeça e pescoço. Comparação da média e desvio padrão da expressão de CXCR1, CXCR2, CXCR3, CXCR5, CCR7, $\mathrm{CX}_{3} \mathrm{CR} 1$, entre amostras de tumor e mucosa adjacente. Cavidade Oral $(n=32){ }^{*} \mathrm{CXCR} 1: \mathrm{p}=0,059$ e ${ }^{*} \mathrm{CXCR} 3 \mathrm{p}=0,030$; Laringe $(n=24){ }^{*} \mathrm{CXCR} 3$ : $p=0,083$; Orofaringe $(n=24)$ e Hipofaringe $(n=9)$ : sem diferenças.

Para avaliar se as diferenças entre tumor e mucosa adjacente são dependentes do tamanho do tumor, dividimos a população em pT1/T2 e pT3/T4 e comparamos cada uma com as respectivas mucosas utilizando o teste-t pareado. Considerando o grupo de tumores menores pT1/pT2 $(n=26)$, CXCR3 e CXCR4 demonstraram um aumento da expressão no tecido tumoral em relação à mucosa $(p=0,044$ e $p=0,007$, respectivamente). Uma tendência ao aumento de expressão de CXCR1 nos tumores também foi observada $(p=0,099)$, sendo que os demais receptores não apresentaram 
diferenças significativas (Tabela 4). No grupo de tumores maiores, pT3/T4 $(n=63)$, somente o gene CXCR3 estava aumentado no tumor $(p=0,045)$ e CXCR1 apresentou uma tendência a aumento também nos tumores $(p=0,064 ;$ Tabela 4$)$.

Tabela 4 - Comparação da média e desvio padrão relativo à expressão dos mRNA dos receptores de quimiocinas entre tumores e mucosa normal adjacente, considerados entre tumores pT1/T2 e pT3/T4. São consideradas diferenças estatísticas $p \leq 0,05$ e marginalmente significantes $p \leq 0,1$.

\begin{tabular}{|c|c|c|c|}
\hline Receptore & & $\begin{array}{c}\mathrm{pT} 1 / \mathrm{T} 2 \\
\mathrm{n}=26 \\
\text { Média + DP }\end{array}$ & $\begin{array}{c}\text { pT3/T4 } \\
n=63 \\
\text { Média + DP }\end{array}$ \\
\hline CXCR1 & $\begin{array}{l}\text { Tumor } \\
\text { Mucosa }\end{array}$ & $\begin{array}{c}0,022 \pm 0,052 \\
0,008 \pm 0,019 \\
p=0,099\end{array}$ & $\begin{array}{c}0,016 \pm 0,036 \\
0,007 \pm 0,014 \\
p=0,064\end{array}$ \\
\hline CXCR2 & $\begin{array}{l}\text { Tumor } \\
\text { Mucosa }\end{array}$ & $\begin{array}{c}0,027 \pm 0,062 \\
0,018 \pm 0,029 \\
p=0,315\end{array}$ & $\begin{array}{c}0,011 \pm 0,018 \\
0,014 \pm 0,021 \\
p=0,282\end{array}$ \\
\hline CXCR3 & $\begin{array}{l}\text { Tumor } \\
\text { Mucosa }\end{array}$ & $\begin{array}{c}0,011 \pm 0,017 \\
0,003 \pm 0,007 \\
p=0,044\end{array}$ & $\begin{array}{c}0,007 \pm 0,009 \\
0,004 \pm 0,008 \\
p=0,045\end{array}$ \\
\hline CXCR4 & $\begin{array}{l}\text { Tumor } \\
\text { Mucosa }\end{array}$ & $\begin{array}{c}0,227 \pm 0,220 \\
0,147 \pm 0,212 \\
p=0,007\end{array}$ & $\begin{array}{c}0,179 \pm 0,120 \\
0,153 \pm 0,203 \\
p=0,273\end{array}$ \\
\hline CXCR5 & $\begin{array}{l}\text { Tumor } \\
\text { Mucosa }\end{array}$ & $\begin{array}{c}0,004 \pm 0,007 \\
0,010 \pm 0,033 \\
p=0,395\end{array}$ & $\begin{array}{c}0,005 \pm 0,009 \\
0,013 \pm 0,042 \\
p=0,159\end{array}$ \\
\hline CCR7 & $\begin{array}{l}\text { Tumor } \\
\text { Mucosa }\end{array}$ & $\begin{array}{c}0,023 \pm 0,037 \\
0,014 \pm 0,027 \\
p=0,129\end{array}$ & $\begin{array}{c}0,012 \pm 0,017 \\
0,024 \pm 0,073 \\
p=0,209\end{array}$ \\
\hline CX3CR1 & $\begin{array}{l}\text { Tumor } \\
\text { Mucosa }\end{array}$ & $\begin{array}{c}0,007 \pm 0,010 \\
0,006 \pm 0,009 \\
p=0,446\end{array}$ & $\begin{array}{c}0,008 \pm 0,012 \\
0,007 \pm 0,017 \\
p=0,567\end{array}$ \\
\hline
\end{tabular}


Outro dado analisado foi a comparação de tumores sem $(\mathrm{pN} 0)$ ou com comprometimento linfonodal $(\mathrm{pN}+)$, e suas respectivas mucosas adjacentes, pelo teste t-pareado. Quando analisamos o grupo pNo ( $n=36)$, CXCR4 e $\mathrm{CX}_{3} \mathrm{CR} 1$ demonstraram um aumento da expressão no tecido tumoral apresentando $p<0,0001$ e $p=0,048$, respectivamente. CXCR1 e CCR7 apresentaram tendência a um aumento de expressão nos tumores $(p=0,050$ e $p=0,078$, respectivamente), sendo que os demais receptores, não apresentaram diferenças significativas (CXCR2: $p=0,510$; CXCR3: $p=0,126$ e CXCR5: $p=0,584)$. No grupo de tumores $p N+(n=53)$, somente o gene CXCR3 teve um aumento no tumor $(p=0,031)$ e CXCR1 apresentou uma tendência a um aumento $(p=0,086)$. Não houve diferenças estatísticas detectáveis para os genes: CXCR2: $p=0,514$; CXCR4: $p=0,456$; CXCR5: $p=0,117 ; \operatorname{CCR} 7: p=0,185 ; C_{3} C R 1: p=0,935$.

Em relação ao tamanho do tumor, não foram detectadas diferenças estatísticas na expressão dos receptores das quimiocinas entre os tumores pT1/T2 e pT3/T4 no grupo como um todo exceto em relação ao receptor CCR7, que teve sua expressão aumentada em tumores menores pT1/T2 $(p=0,023)$ em relação aos maiores $p T 3 / T 4$ e ao receptor CXCR3 que obteve esta mesma tendência $(p=0,072)$ (Tabela 5$)$. Em relação aos sítios estudados, somente em laringe há uma maior expressão de CCR7 em tumores $p T 1 / T 2(p=0,012)$. Os demais receptores não tiveram diferenças estatísticas entre os grupos estudados. Não foi possível realizar a análise estatística do sítio hipofaringe, uma vez que este apresenta um único caso de tumor $\mathrm{pT} 1 / \mathrm{T} 2$ (Tabela 5). 
Tabela 5 - Comparação da média e desvio padrão relativo à expressão do RNA mensageiro dos receptores de quimiocinas entre tumores pT1/T2 e pT3/T4. Foram considerados os pacientes como um todo (HNSCC) e os demais sítios tumorais estudados. São consideradas diferenças estatísticas $p \leq 0,05$ e marginalmente significantes $p \leq 0,1$ (teste $T$ nãopareado).

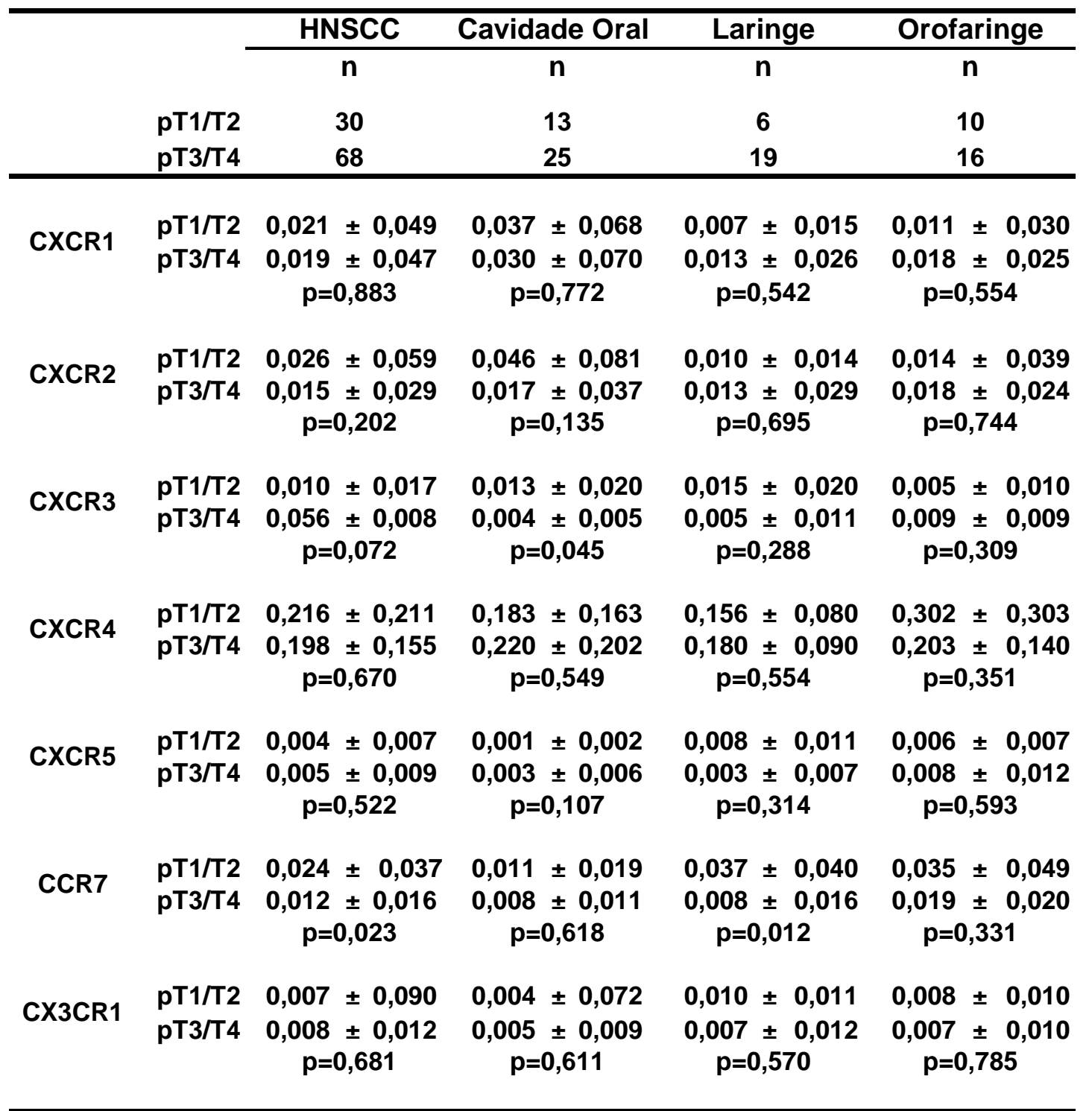


Avaliamos também, se haviam diferenças estatísticas entre os grupos de tumor de pacientes pN0 e pN+. Considerando o grupo como um todo e os demais sítios analisados, não foram verificadas diferenças significantes entre os tumores pN0 e pN+. Somente no sítio Hipofaringe observamos um aumento de expressão do gene CXCR5 nos tumores $p N+(p=0,007)$. Porém a comparação foi realizada entre duas amostras pN0 e sete amostras pN+, ou seja, com um número muito pequeno de amostras (Tabela 6, figura 6). 

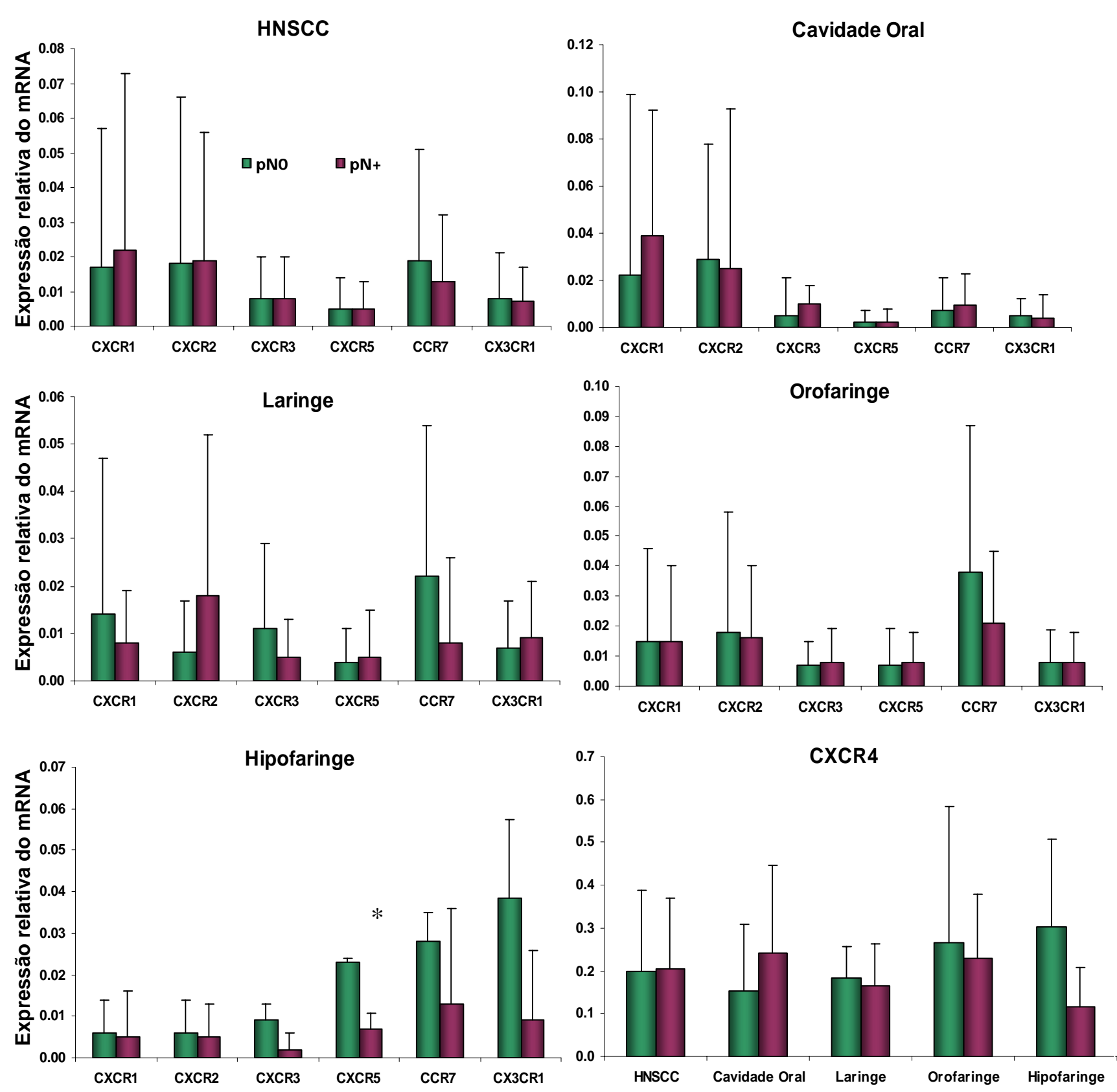

Figura 6 - Comparação da expressão do mRNA de receptores de quimiocinas, entre tumores pNO e pN+ em HNSCC $(n=98)$, Cavidade Oral $(n=38)$, Laringe $(n=25)$, Orofaringe $(n=26)$ e Hipofaringe $(n=9$, *CXCR5 $p=0,007)$. 
Tabela 6 - Comparação da média e desvio padrão relativo à expressão dos mRNA dos receptores de quimiocinas entre tumores pNO e pN+. Foi considerado o grupo como um todo e os sítios tumorais estudados. Foram consideradas diferenças estatísticas $p \leq 0,05$ e marginalmente significantes $p \leq 0,1$.

\begin{tabular}{|c|c|c|c|c|c|c|}
\hline & & HNSCC & Cavidade Oral & Laringe & Orofaringe & Hipofaringe \\
\hline \multirow{2}{*}{\multicolumn{2}{|c|}{$\begin{array}{l}\text { n pN+ } \\
\text { n pNo }\end{array}$}} & 59 & 23 & 13 & 17 & 7 \\
\hline & & 39 & 15 & 12 & 9 & 2 \\
\hline \multirow{2}{*}{ CXCR1 } & $\mathrm{pN}+$ & $0,021 \pm 0,051$ & $0,039 \pm 0,077$ & $0,008 \pm 0,011$ & $0,015 \pm 0,025$ & $0,005 \pm 0,011$ \\
\hline & pNO & $\begin{array}{c}0,017 \pm 0,040 \\
p=0,609\end{array}$ & $\begin{array}{c}0,022 \pm 0,053 \\
p=0,420\end{array}$ & $\begin{array}{c}0,014 \pm 0,033 \\
p=0,559\end{array}$ & $\begin{array}{c}0,015 \pm 0,031 \\
p=0,974\end{array}$ & $\begin{array}{c}0,006 \pm 0,008 \\
p=0,993\end{array}$ \\
\hline \multirow{2}{*}{ CXCR2 } & $\mathrm{pN}+$ & $0,019 \pm 0,037$ & $0,025 \pm 0,049$ & $0,018 \pm 0,034$ & $0,016 \pm 0,024$ & $0,005 \pm 0,008$ \\
\hline & pNO & $\begin{array}{c}0,018 \pm 0,047 \\
p=0,950\end{array}$ & $\begin{array}{c}0,029 \pm 0,068 \\
p=0,844\end{array}$ & $\begin{array}{c}0,006 \pm 0,011 \\
p=0,252\end{array}$ & $\begin{array}{c}0,018 \pm 0,041 \\
p=0,879\end{array}$ & $\begin{array}{c}0,006 \pm 0,008 \\
p=0,942\end{array}$ \\
\hline \multirow{2}{*}{ CXCR3 } & $\mathrm{pN}+$ & $0,007 \pm 0,012$ & $0,010 \pm 0,016$ & $0,005 \pm 0,008$ & $0,008 \pm 0,011$ & $0,002 \pm 0,004$ \\
\hline & pNO & $\begin{array}{c}0,008 \pm 0,012 \\
p=0,957\end{array}$ & $\begin{array}{c}0,005 \pm 0,008 \\
p=0,228\end{array}$ & $\begin{array}{c}0,011 \pm 0,017 \\
p=0,337\end{array}$ & $\begin{array}{c}0,007 \pm 0,008 \\
p=0.823\end{array}$ & $\begin{array}{c}0,009 \pm 0,004 \\
p=0,171\end{array}$ \\
\hline \multirow{2}{*}{ CXCR4 } & $\mathrm{pN}+$ & $0,206 \pm 0,163$ & $0,240 \pm 0,205$ & $0,167 \pm 0,097$ & $0,228 \pm 0,150$ & $0,115 \pm 0,094$ \\
\hline & pNO & $\begin{array}{c}0,197 \pm 0,191 \\
p=0,805\end{array}$ & $\begin{array}{c}0,153 \pm 0,155 \\
p=0,148\end{array}$ & $\begin{array}{c}0,182 \pm 0,077 \\
p=0,656\end{array}$ & $\begin{array}{c}0,265 \pm 0,318 \\
p=0,747\end{array}$ & $\begin{array}{c}0,304 \pm 0,204 \\
p=0,406\end{array}$ \\
\hline \multirow{2}{*}{ CXCR5 } & $\mathrm{pN}+$ & $0,005 \pm 0,008$ & $0,002 \pm 0,005$ & $0,005 \pm 0,010$ & $0,008 \pm 0,010$ & $0,007 \pm 0,010$ \\
\hline & pNO & $\begin{array}{c}0,005 \pm 0,009 \\
p=0,921\end{array}$ & $\begin{array}{c}0,002 \pm 0,006 \\
p=0,857\end{array}$ & $\begin{array}{c}0,004 \pm 0,007 \\
p=0,854\end{array}$ & $\begin{array}{c}0,007 \pm 0,012 \\
p=0,845\end{array}$ & $\begin{array}{c}0,002 \pm 0,007 \\
p=0,007\end{array}$ \\
\hline \multirow{2}{*}{ CCR7 } & $\mathrm{pN}+$ & $0,013 \pm 0,019$ & $0,010 \pm 0,014$ & $0,008 \pm 0,018$ & $0,021 \pm 0,024$ & $0,013 \pm 0,023$ \\
\hline & pNO & $\begin{array}{c}0,019 \pm 0,032 \\
p=0,258\end{array}$ & $\begin{array}{c}0,007 \pm 0,014 \\
p=0,658\end{array}$ & $\begin{array}{c}0,022 \pm 0,032 \\
p=0,218\end{array}$ & $\begin{array}{c}0,034 \pm 0,049 \\
p=0,461\end{array}$ & $\begin{array}{c}0,028 \pm 0,007 \\
p=0,174\end{array}$ \\
\hline \multirow{2}{*}{ CX3CR1 } & $\mathrm{pN}+$ & $0,007 \pm 0,010$ & $0,004 \pm 0,007$ & $0,009 \pm 0,012$ & $0,008 \pm 0,010$ & $0,010 \pm 0,017$ \\
\hline & pNO & $\begin{array}{c}0,008 \pm 0,013 \\
p=0,589\end{array}$ & $\begin{array}{c}0,005 \pm 0,010 \\
p=0,798\end{array}$ & $\begin{array}{c}0,007 \pm 0,010 \\
p=0,695\end{array}$ & $\begin{array}{c}0,008 \pm 0,011 \\
p=0,955\end{array}$ & $\begin{array}{c}0,004 \pm 0,019 \\
p=0,233\end{array}$ \\
\hline
\end{tabular}

A seguir, avaliamos a expressão desses receptores de quimiocinas em 26 linfonodos comprometidos (LNT) e comparamos com a expressão dos tumores primários $(\mathrm{T})$. Considerando os tumores de cabeça e pescoço de um modo geral, observamos que os linfonodos comprometidos tiveram maior expressão de vários receptores, como: CXCR4 (LNT: 0,405 \pm 0,228 vs 0,205 \pm 0,108: T, p s0,0001), CXCR5 (LNT: 0,042 $\pm 0,037$ vs 0,004 $\pm 0,008: T$, 
$\mathrm{p} \leq 0,0001$ ), CCR7 (LNT: $0,078 \pm 0,074$ vs 0,012 $\pm 0,021: \mathrm{T}, \mathrm{p} \leq 0,0001), \mathrm{e}$ $\mathrm{CX}_{3} \mathrm{CR} 1$ (LNT: $0,033 \pm 0,033$ vs 0,007 $\pm 0,011: \mathrm{T}, \mathrm{p} \leq 0,0001$ ). Uma tendência ao aumento de expressão do receptor $\operatorname{CXCR2}(p=0,063)$ nos linfonodos comprometidos também foi observada. Porém, os demais receptores como CXCR1 $(p=0,064)$ e CXCR3 $(p=0,062)$ apresentaram uma tendência à diminuição nos linfonodos comprometidos (Figura 7 e 8).
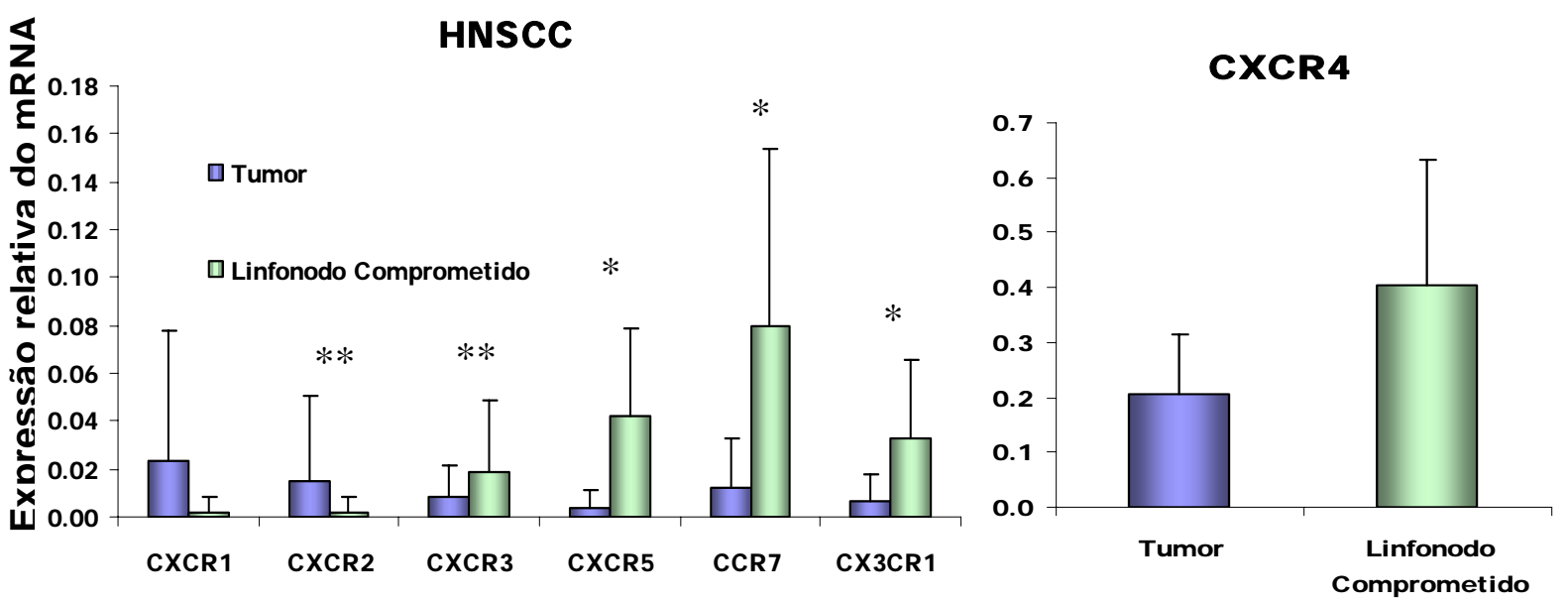

\begin{tabular}{|c|c|c|c|c|c|c|c|}
\hline$n=26$ & CXCR1 & CXCR2 & CXCR3 & CXCR4 & CXCR5 & CCR7 & CX3CR1 \\
\hline Significância & $p=0,064$ & $p=0,063$ & $p=0,062$ & $p<0,001$ & $p<0,001$ & $p<0,001$ & $p<0,001$ \\
\hline
\end{tabular}

Figura 7/Tabela 7 - Comparação da média e desvio padrão relativos á expressão do RNA mensageiro dos receptores de quimiocinas entre tumores e linfonodos comprometidos em HNSCC. (Teste T-pareado, $n=26$, ${ }^{*} p \leq 0,05$ e $\left.{ }^{* *} p \leq 0,1\right)$. 


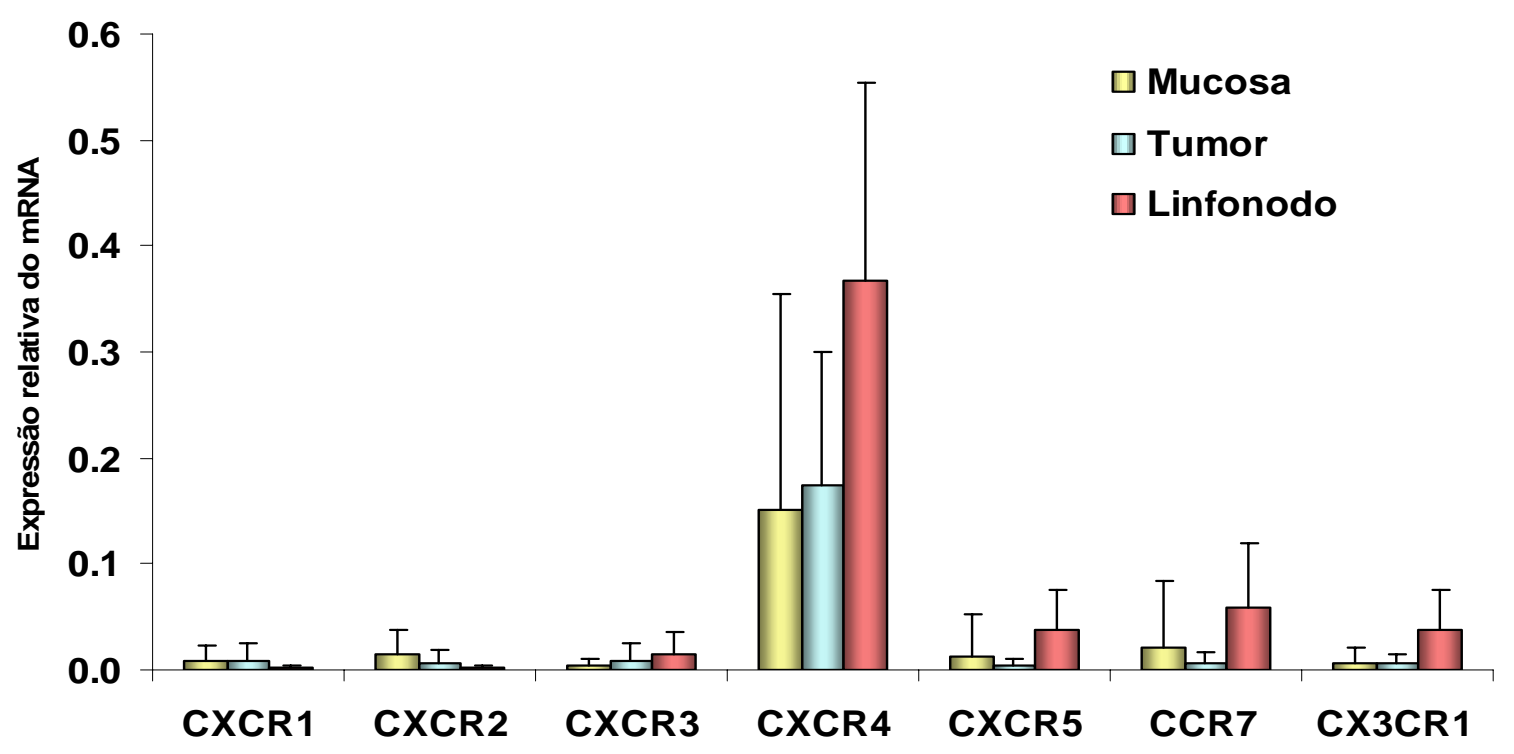

Figura 8 - Expressão dos mRNA de receptores de quimiocinas em HNSCC. Comparação da média e desvio padrão relativos à expressão de cada receptor nas amostras de tumor, mucosa adjacente e linfonodos (teste T pareado). 


\section{2- Análise da Sobrevida Global e Livre de Doença}

A etapa seguinte deste trabalho foi avaliar se a expressão dos receptores de quimiocinas apresentava alguma associação com a sobrevida global e sobrevida livre de doença desses pacientes. Para isso, os pacientes foram divididos em receptores positivos ou negativos em relação à mediana da expressão dos respectivos receptores nos tumores primários: positivo quando a expressão foi superior e negativo, expressão inferior ou igual à mediana.

O seguimento dos pacientes como um todo foi em média de 23,67 meses. Considerando os pacientes como um todo, a mediana de sobrevida global dos pacientes receptor de quimiocina negativo e positivo, respectivamente foi de 26,60 e de 19,77 meses para CXCR1; de 24,83 e 27,97 meses para CXCR2; de 26,60 e 19,77 meses para CXCR3; de 26,13 e 22,47 meses para CXCR4; de 26,60 e 20,07 meses para CXCR5; de 30,87 e 18,77 meses para CCR7; de 26,60 e 20,07 meses para CX $_{3}$ CR1. A comparação das curvas de Kaplan-Meier pelo teste de Log Rank revelou não haver diferenças entre os grupos receptor positivo e negativo (figura 9).

Verificamos a seguir, se havia associação entre a expressão dos receptores e a recidiva da doença. A comparação das curvas de sobrevida livre de doença, também não mostrou diferenças entre as duas populações (figura 10). 


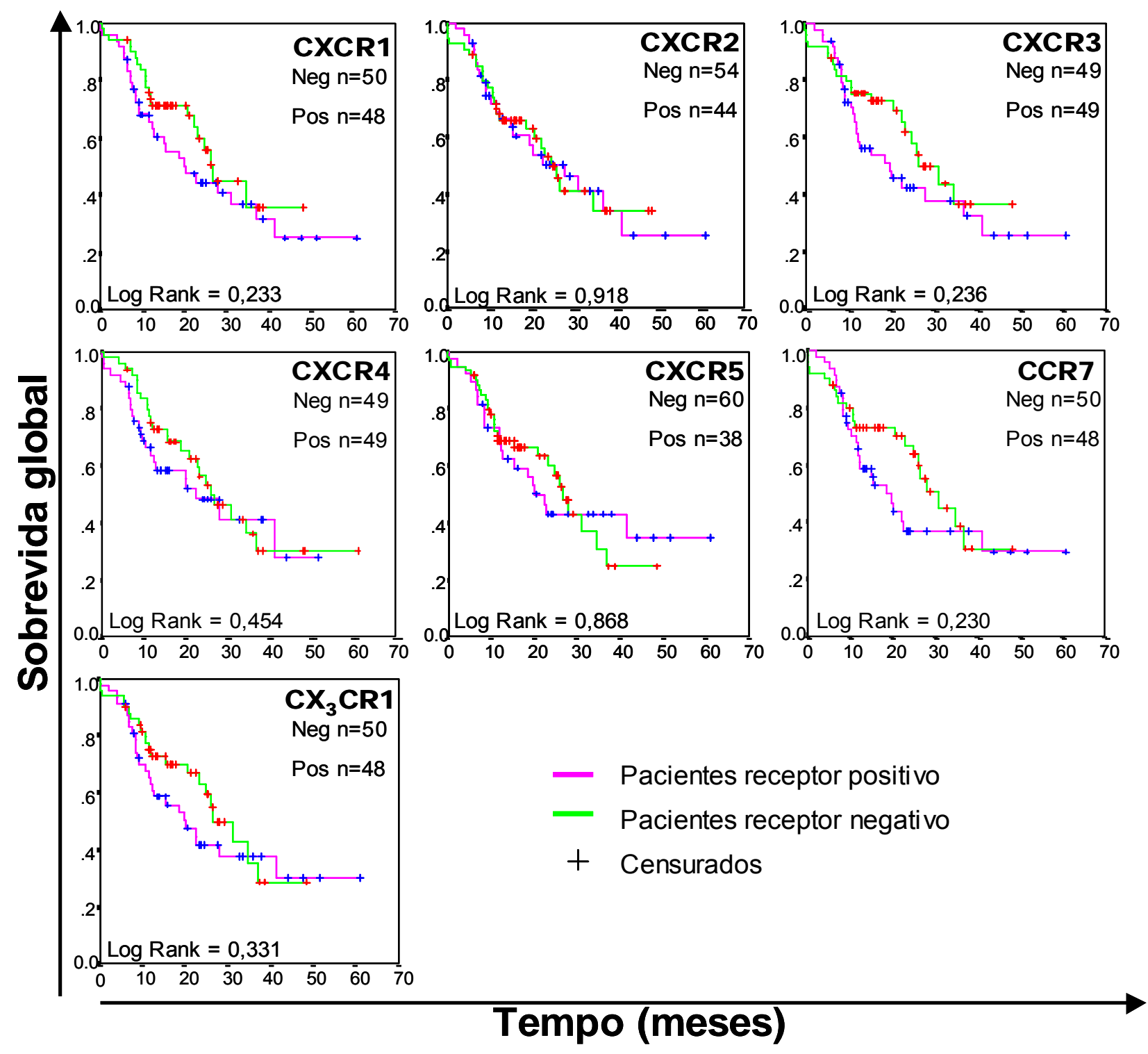

Figura 9 - Curvas de sobrevida global de pacientes portadores de HNSCC. Nesta figura vemos as Curvas de Kaplan-Meier dos pacientes agrupados em positivo (superior) e negativo (inferior ou igual) segundo a mediana de expressão de receptores de quimiocinas nos tumores. A comparação entre as curvas foi realizada segundo o teste de Log Rank. 


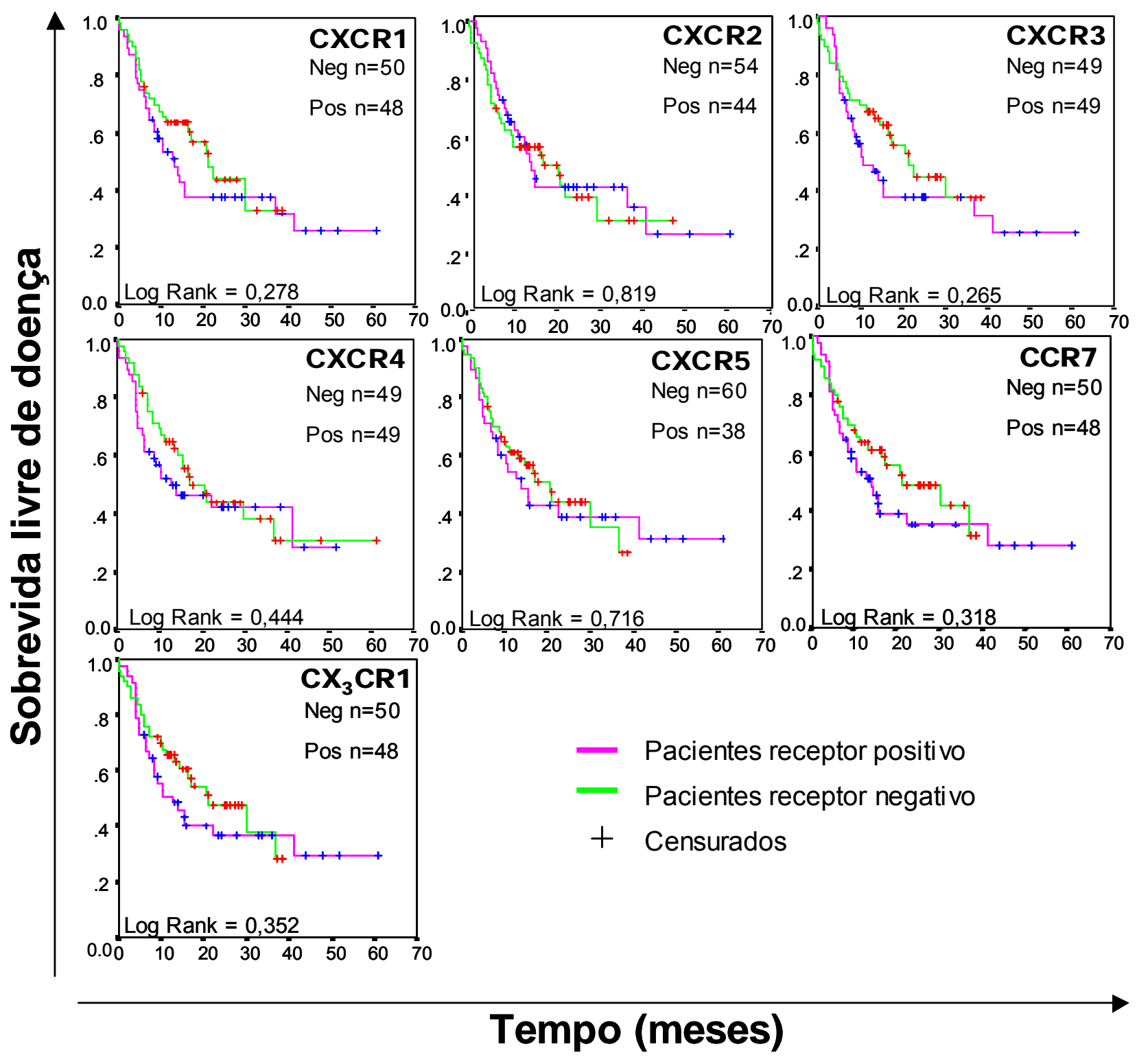

Figura 10 - Curvas de sobrevida livre de doença de pacientes portadores de HNSCC. Nesta figura vemos as Curvas de Kaplan-Meier dos pacientes agrupados em positivo (superior, linhas na cor rosa) e negativo (inferior ou igual, linhas na cor verde) segundo a mediana de expressão de receptores de quimiocinas nos tumores. A comparação entre as curvas foi realizada segundo o teste de Log Rank. 
Subdividindo os pacientes quanto ao sítio primário do tumor, verificamos que os pacientes com tumores de cavidade oral: CXCR3 (Log Rank=0,049), CCR7 (Log Rank=0,024) e CX ${ }_{3}$ CR1 (Log Rank=0,048) negativos apresentam uma vantagem de sobrevida em relação ao grupo positivo. A mediana de sobrevida global para os três marcadores foi de 34,63 meses no grupo negativo e de 11,60 meses no grupo positivo (figura 11).

Em relação à sobrevida livre de doença, somente o grupo CCR7 negativo (mediana: 20,70 meses) manteve vantagem sobre o grupo positivo (mediana: 7,07 meses; LogRank=0,049). Enquanto que no grupo $\mathrm{CX}_{3} \mathrm{CR} 1$ negativo (mediana: 20,70 meses), apenas uma tendência pode ser observada (mediana do grupo positivo: 7,07; LogRank=0,074). As curvas de Kaplan-Meier estão representadas na figura 12.

Pela análise de Log Rank, observamos que os pacientes CCR7 $(p=0,049)$ e $C X_{3} C R 1 \quad(p=0,074)$ negativos apresentam uma vantagem de sobrevida em relação ao grupo positivo. Os outros receptores não obtiveram diferenças significantes: CXCR1 $p=0,707, \quad$ CXCR2 $p=0,639, \quad$ CXCR3 $p=0,232, \operatorname{CXCR} 4 p=0,649$ e CXCR5 $p=0,112$. 


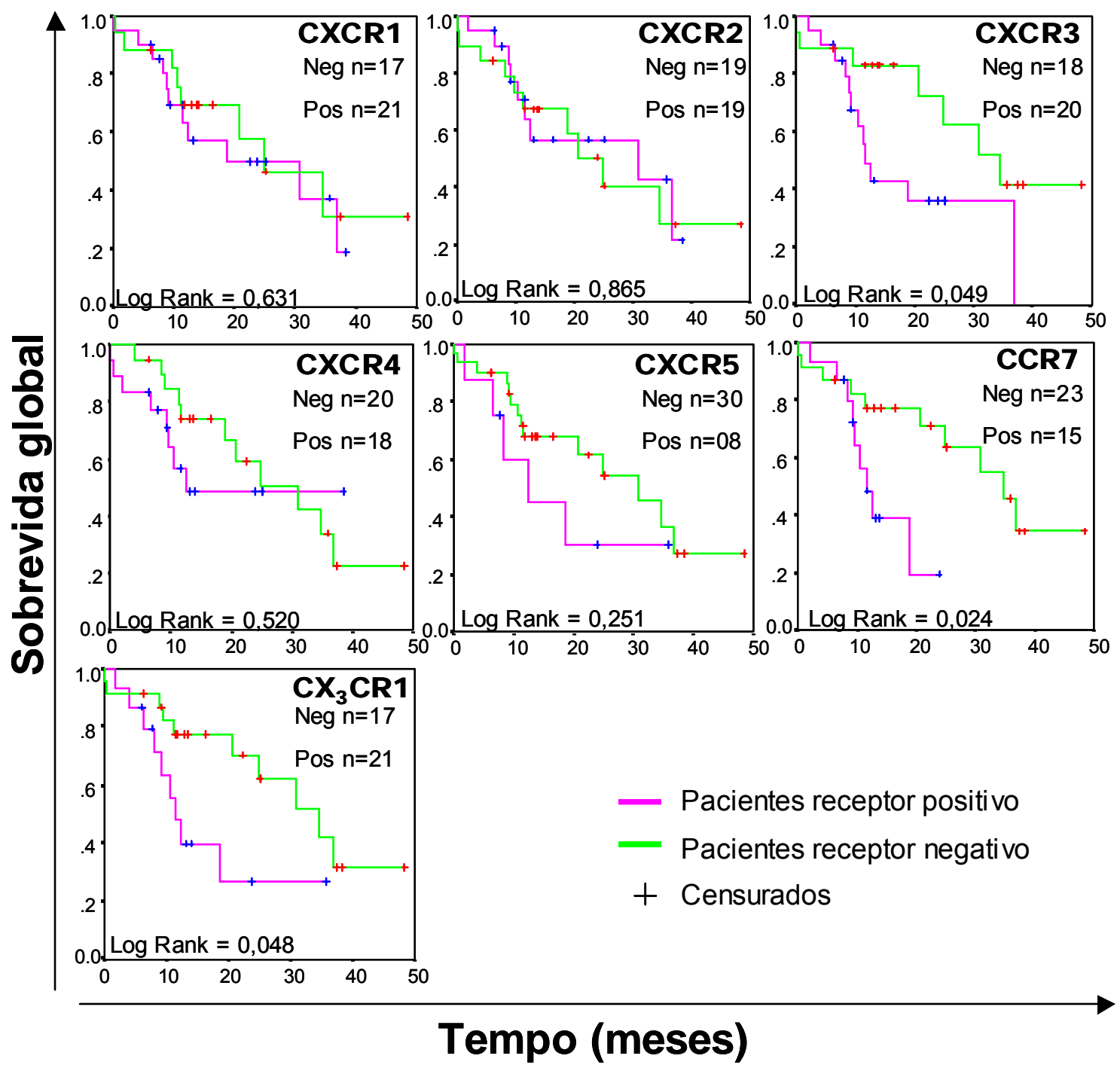

Figura 11 - Curvas de sobrevida global de pacientes portadores de carcinoma epidermóide de Cavidade Oral. Nesta figura vemos as Curvas de Kaplan-Meier dos pacientes agrupados em positivo (superior, linhas na cor rosa) e negativo (inferior ou igual, linhas na cor verde) segundo a mediana de expressão de receptores de quimiocinas nos tumores. A comparação entre as curvas foi realizada segundo o teste de Log Rank. 


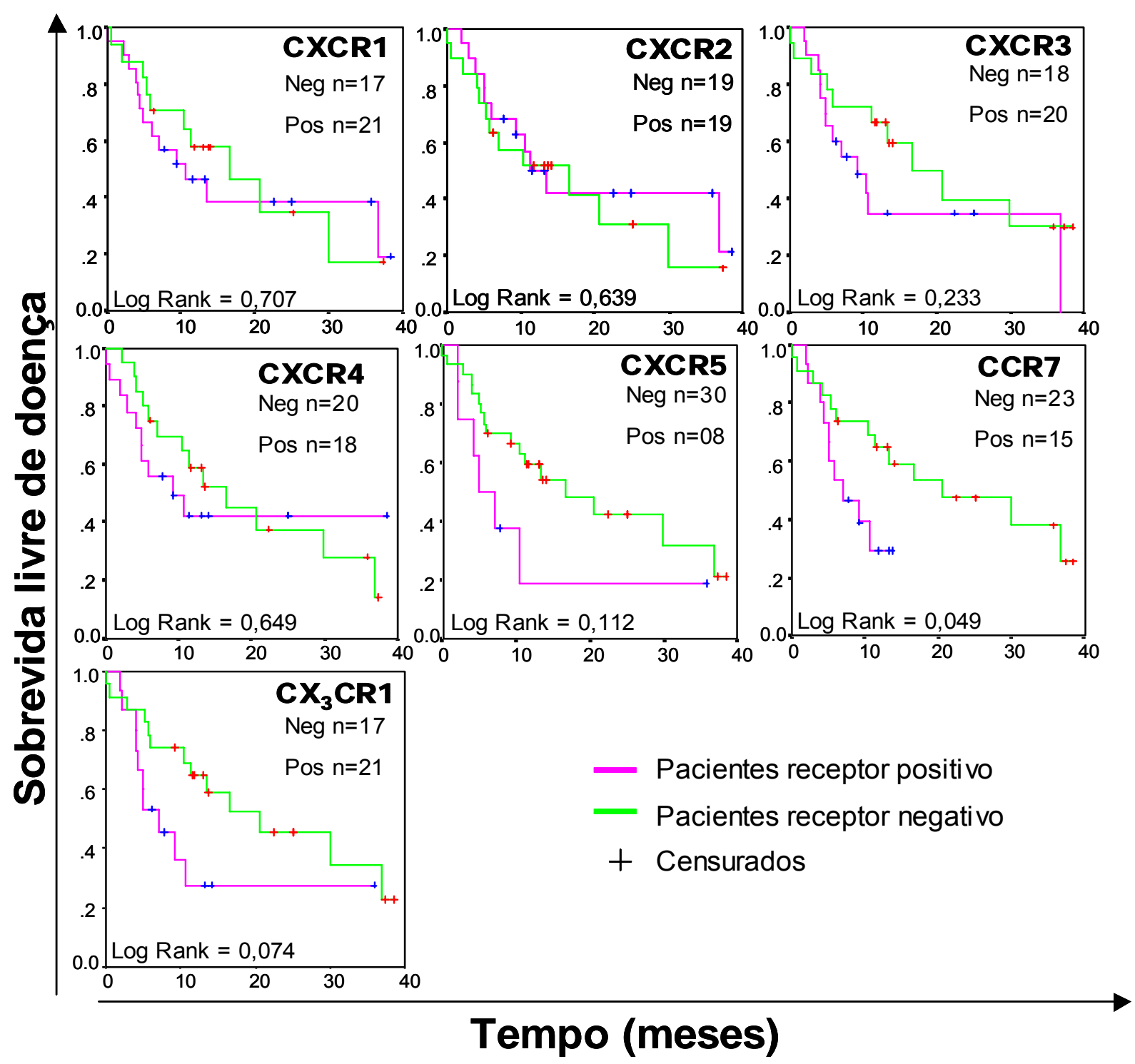

Figura 12 - Curvas de sobrevida livre de doença de pacientes portadores de carcinoma epidermóide de Cavidade Oral. Nesta figura vemos as Curvas de Kaplan-Meier dos pacientes agrupados em positivo (superior, linhas na cor rosa) e negativo (inferior ou igual, linhas na cor verde) segundo a mediana de expressão de receptores de quimiocinas nos tumores. A comparação entre as curvas foi realizada segundo o teste de Log Rank. 
No grupo laringe, houve tendência a vantagem de sobrevida global somente no grupo de pacientes CXCR1 ( $p=0,053)$ negativo (dados não mostrados). Quanto à sobrevida livre de doença, esse mesmo grupo de pacientes apresentou um maior intervalo livre de recidiva quando comparado ao grupo CXCR1 positivo (LogRank=0,020). Os demais receptores não apresentaram associações com a sobrevida dos pacientes com carcinoma de laringe. Nos pacientes portadores de HNSCC de orofaringe e hipofaringe, nenhuma associação com sobrevida global e livre de doença pode ser observada.

\section{3- Análise dos ligantes de quimiocinas}

Segundo dados da literatura, os receptores CXCR4 e CCR7 e, mais recentemente, o $\mathrm{CX}_{3} \mathrm{CR} 1$ parecem ter importância no processo de metástase tumoral. Diante desses achados, embora nossos resultados não tenham confirmado diferenças significativas na expressão dos receptores entre tumor e mucosa adjacente, avaliamos o perfil de expressão de CXCL12/SDF-1, ligante de CXCR4, CCL19/MIP-3 $\beta$ e CCL21/6Chine, ligantes de $\mathrm{CCR} 7$, e de $\mathrm{CX}_{3} \mathrm{CL} 1$, ligante de $\mathrm{CX}_{3} \mathrm{CR} 1$.

Nesta etapa do estudo, a determinação da expressão dos mRNA desses ligantes, por RT-PCR em tempo real, foi realizada em um total de 38 amostras de tumor, 33 de mucosa adjacente e 25 de linfonodos comprometidos.

A concentração de cDNA padronizada para os ensaios foi de $100 \mathrm{ng}$. Os RNAs mensageiros das quimiocinas CXCL12, CCL19, CCL21 e CX ${ }_{3} \mathrm{CL} 1$ 
foram quantificados relativamente à expressão de um gene controle Beta actina subtraindo a média de valores do ciclo limiar (Ct) deste gene da média do $\mathrm{Ct}$ gerado pelo gene interesse. Este valor é chamado de $\Delta \mathrm{Ct}$. Ao $\Delta \mathrm{Ct}$ obtido da amostra do gene interesse é então, subtraído o $\Delta$ Ct de uma amostra que é utilizada como calibrador, no nosso caso, um tecido normal de boca (gengiva). Este valor é chamado de $\Delta \Delta \mathrm{Ct}$. O valor da relação que é utilizado para a análise estatística é calculado: potência de 2 elevada a $\Delta \Delta \mathrm{Ct}\left(2^{-\Delta \Delta C t}\right)$. Este valor corresponde à expressão do mRNA do gene estudado em relação ao tecido normal.

A comparação da expressão dos ligantes entre tumor e mucosa adjacente revelou não haver diferenças entre os dois grupos (CXCL12 $p=0,181 ; \operatorname{CCL} 19 p=0,653 ; \operatorname{CCL} 21 p=0,610$ e $\left.C X_{3} C L 1 p=0,357\right)$. Quando os tumores da cavidade oral $(n=13)$, laringe $(n=8)$ ou orofaringe $(n=9)$ foram considerados separadamente esse mesmo padrão se manteve.

Levando-se em conta o status nodal, verificamos que também não há diferença na expressão dos quatro ligantes estudados entre tumor pNO $(n=10)$ e $\mathrm{pN}+(\mathrm{n}=28)$ no grupo como um todo. Nos tumores da cavidade oral, observamos uma diminuição na expressão de CCL19 no grupo pN+ $[\mathrm{pN}+$ $(n=12): 0,81 \pm 0,77$ vs $4,27 \pm 3,71: p N 0(n=4), P=0,006]$. Em laringe $[p N+$ $(n=6): 0,83 \pm 0,41, P=0,004]$ e em orofaringe $[p N+(n=8): 0,50 \pm 0,53, P=$ $0,03]$.

Por fim, comparamos a expressão dos ligantes entre tumor e linfonodo comprometido e observamos que, no grupo como um todo $(n=25)$, apenas o ligante $\mathrm{CX}_{3} \mathrm{CL} 1 \quad(p=0,060$, figura 13$)$ teve sua expressão marginalmente diminuída nos linfonodos comprometidos. Na cavidade oral 
( $n=13)$, observamos uma tendência ao aumento da expressão de CCL21 nos linfonodos $(p=0,059)$. Em laringe $(n=6)$, essa mesma quimiocina está superexpressa nos linfonodos comprometidos (CCL21 $P=0,048)$ enquanto que a CCL19 apresentou apenas uma tendência ao aumento de expressão $(p=0,073)$. Em orofaringe $(n=9)$, à semelhança do que ocorreu no grupo como um todo, a expressão de $\mathrm{CX}_{3} \mathrm{CL} 1$ teve sua expressão reduzida nos linfonodos $(p=0,019)$.

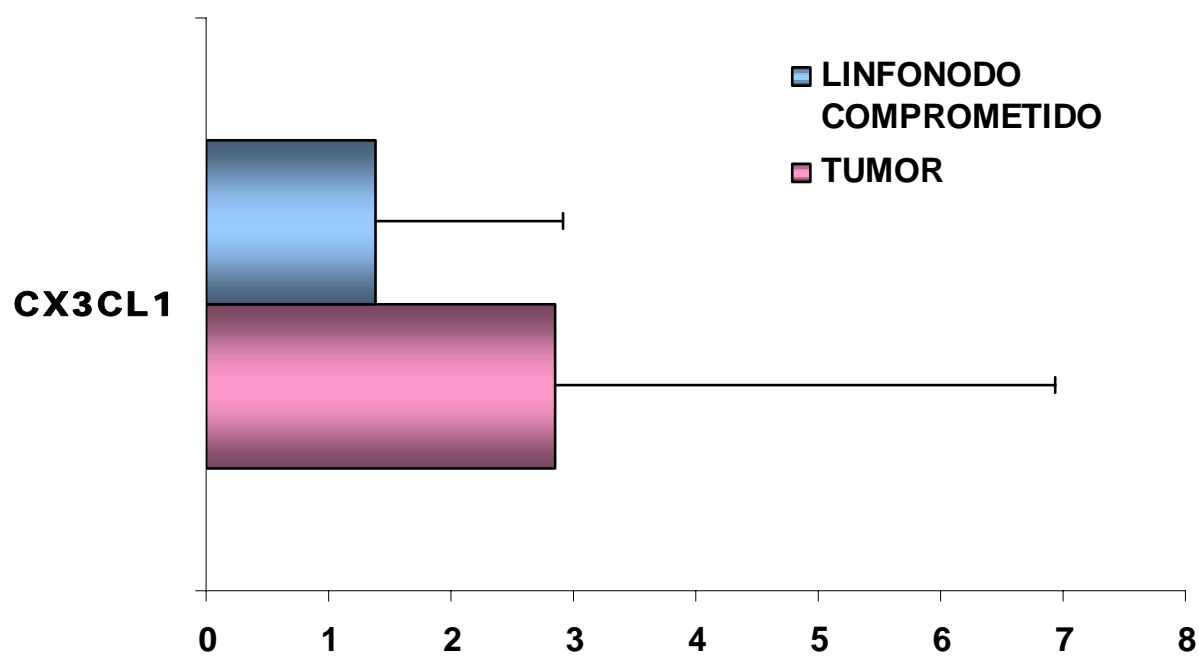

Figura 13 - Expressão relativa do ligante de quimiocinas $\mathrm{CX}_{3} \mathrm{CL1}$ comparando a expressão entre tumores primários e linfonodos comprometidos ( $n=25$, $p=0,060$ ). 
Discussão 


\section{5- Discussão}

As interações específicas entre os receptores de quimiocinas e seus ligantes parecem contribuir para a disseminação metastática e influenciar a sobrevida em muitos modelos de câncer (Müller et al. 2001, revisado em Zlotnik, 2004 e Kulbe et al. 2004). Colaborando com esta idéia, verificamos que os receptores de quimiocinas estão expressos de forma variável em todos os HNSCC em nosso trabalho.

Uma grande parte dos receptores aqui estudados estavam expressos em metade das amostras, exceção feita ao receptor CXCR4 que foi expresso em todas as amostras. Se a hipótese de que os receptores de quimiocinas possam ter um papel no processo de invasão celular estiver certa, o esperado é que houvesse um gradiente de concentração desses receptores entre tumor primário e a mucosa adjacente. De acordo com isso, em nosso trabalho, encontramos um aumento do mRNA dos receptores CXCR1, CXCR3 e CXCR4 em tumores primários em relação à mucosa adjacente.

Dentre os receptores de quimiocinas estudados, o receptor CXCR4 tem sido apontado com o mais importante em metástases à distância, como metástases para o pulmão, fígado e medula óssea (Zlotnik, 2004). Em muitos tipos diferentes de câncer, CXCR4 tem sido citado como fator determinante na destinação das células tumorais em modelos de câncer de mama, ovário, próstata, rim, cérebro, tireóide e, mais recentemente, o 
interesse tem sido sobre câncer epidermóide da cavidade oral e câncer de cabeça e pescoço em geral (Müller et al. 2001, Scotton et al. 2001, Taichman et al. 2002, Schrader et al. 2002, Zhou et al. 2002, Hwang et al. 2003, Uchida et al. 2003, Samara et al. 2004). Não foi surpresa portanto, que CXCR4 estivesse expresso em todos os fragmentos de tumor estudados, sugerindo que pudesse ser alvo precoce durante a carcinogênese. Isso explicaria a ausência de correlações entre a expressão de CXCR4 e o estádio TNM dos tumores em nosso grupo de pacientes. Porém, discordando de nossos resultados, Ishikawa et al. 2006 verificaram em tumores de cavidade oral, embora com outra metodologia, que apenas $30 \%$ expressavam a proteína CXCR4 por imunohistoquímica.

Em nosso estudo, observamos somente uma tendência à correlação entre a positividade de CXCR4 e uma pior sobrevida no grupo de tumores mais avançados (pT3/T4), que corresponde a $67,32 \%$ dos nossos pacientes, porém, esta correlação não foi vista no grupo como um todo (dados não mostrados). Nós verificamos um aumento na expressão do mRNA de CXCR4 em carcinoma epidermóide de cavidade oral em comparação com a mucosa adjacente. Esse dado concorda, em parte, com os resultados obtidos por imunohistoquímica nesse mesmo tipo de tumor, mostrando uma significante associação entre a positividade de CXCR4 e a presença de linfonodos comprometidos, invasão e prognóstico (Almofti et al. 2004).

Estes autores mostram ainda uma associação entre esse marcador e a sobrevida global, sendo que a taxa de sobrevida de 5 anos foi de $56,8 \%$ para o grupo de pacientes positivo e de $83,3 \%$ para o grupo negativo. 
Outros trabalhos demonstram que, após a interação de CXCL12 com CXCR4, ocorre a ativação tanto de ERK1/2 quanto de Akt/PKB em carcinoma epidermóide de cavidade oral, sugerindo que esta via seja funcional e possa ter um papel importante no processo de metástase para os linfonodos (Uchida et al. 2003 e 2004). De forma similar, Samara et al. (2004) demonstraram que a ativação da via de ERK1/2 por CXCR4/CXCL12 pode induzir a secreção de MMP-9 ativa em linhagens de HNSCC. Assim, de maneira indireta, é possível que CXCR4 seja capaz de influenciar o comportamento invasivo da periferia do tumor, inferindo que a via CXCL12/CXCR4 seja um alvo terapêutico potencial em HNSCC, conforme foi recentemente sugerido para o tratamento adjuvante em câncer de mama (Epstein, 2004).

Como a grande maioria de nossos pacientes é diagnosticada em estádio muito avançado, existe a possibilidade de que a expressão do mRNA de CXCR4 esteja uniformemente alta em todos os pacientes ou de que o método empregado não tenha sido sensível a ponto de detectar pequenas diferenças entre os pacientes. Talvez essa seja a razão pela qual não tenhamos encontrado associações com sobrevida global dos pacientes. De acordo com isso, Uchida et al. (2003) também não encontrou correlações entre a expressão de CXCR4 e sobrevida em uma população de pacientes portadores de carcinoma epidermóide de cavidade oral, usando o método de RT-PCR semi-quantitativa. Por outro lado, ao menos na linhagem celular estudada B88, a funcionalidade da via foi demonstrada por Uchida et al. 
(2003, 2004) através da ativação tanto de ERK1/2 como de Akt/P por CXCR4/CXCL12.

É possível que CXCR4 tenha algum papel na disseminação da doença para os linfonodos adjacentes, conforme foi sugerido por Uchida et al. (2003 e 2004). De acordo com isso, observamos uma alta expressão de CXCR4 nos linfonodos comprometidos quando comparada à do tumor. Em outro estudo, envolvendo 61 pacientes com carcinoma epidermóide de cavidade oral, também foi demonstrada uma relação direta entre a expressão de CXCR4 por imunohistoquímica e metástases linfonodais (Almofti et al. 2004). Mais recentemente, essa correlação entre o aumento de CXCR4 e metástases linfonodais em câncer oral também foi descrita por Ishikawa et al. (2006).

Um outro receptor de quimiocina tão estudado quanto CXCR4 e que parece estar envolvido em disseminações metastáticas para os linfonodos é o receptor CCR7 (Zlotnik, 2004, Kulbe et al. 2004). Experimentos utilizando anticorpos bloqueadores demonstraram que, em linhagens celulares de HNSCC, o CCR7 é funcional e uma alta expressão do seu mRNA foi observada pelo método de RT-PCR semi-quantitativa em linhagens celulares metastáticas de HNSCC (Wang et al. 2004). Em nosso estudo, embora nós não tenhamos observado correlações entre o status nodal e a expressão de CCR7 e nem entre tumor primário e mucosa, verificamos um aumento significativo de CCR7 tanto nos linfonodos em HNSCC como um todo quanto em cavidade oral e orofaringe isoladamente. 
Em um estudo publicado em 1999, foi demonstrado que células dendríticas ativadas se direcionam para os linfonodos através de vasos linfáticos por um mecanismo dependente de CCR7, e que CCL21 é a principal quimiocina implicada no direcionamento de linfócitos para os órgãos secundários (Gunn et al. 1999). Mesmo em cânceres de mama, onde existe uma relação entre a expressão de CXCR4 e metástases à distância, há evidências que indicam que CCR7 possa ser o candidato responsável pela disseminação metastática para linfonodos (Muller et al. 2001). Assim, a tendência ao aumento de expressão de CCL21 nos linfonodos comprometidos observada por nós, pode indicar que esse ligante seja um grande candidato a atrair as células tumorais da cavidade oral que expressam CCR7.

Embora nós não pudéssemos perceber a influência da expressão do mRNA de CCR7 na sobrevida dos pacientes portadores de HNSCC como um todo, verificamos uma correlação entre a positividade de CCR7 e uma menor sobrevida global e livre de doença para pacientes com carcinomas epidermóides da cavidade oral. De forma semelhante, a correlação entre a negatividade de CCR7 detectada por imunohistoquímica e uma maior sobrevida global, também foi sugerida em estudos envolvendo 64 pacientes com carcinomas gástricos e 96 pacientes com carcinomas esofágicos (Mashino et al. 2002 e Ding et al. 2003). Uma possível explicação para este fato é que nestes tipos de câncer, assim como em HNSCC, os pacientes em geral vêm a óbito por doença loco-regional e não por metástases à distância, e por isso CCR7 possa ser importante na sobrevida destes pacientes. Talvez 
em cânceres como os de mama, nos quais a disseminação sistêmica da doença seja crucial para a sobrevida dos pacientes, a relação do receptor CXCR4 possa suplantar o efeito de CCR7 na sobrevida dos pacientes.

Os receptores CXCR5 e $\mathrm{CX}_{3} \mathrm{CR} 1$, em adição aos receptores CXCR4 e CCR7, também se encontram aumentados nos linfonodos comprometidos em relação aos tumores primários, nós aventamos a hipótese de que esses marcadores também possam ter um impacto na sobrevida dos pacientes estudado. Entretanto, nós só pudemos observar uma tendência a um maior intervalo livre de doença para os pacientes $\mathrm{CX}_{3} \mathrm{CR} 1$ negativos no grupo como um todo e naqueles portadores de tumor primário de laringe. Já os pacientes com tumor de cavidade oral $\mathrm{CX}_{3} \mathrm{CR} 1$ negativo apresentaram uma maior sobrevida livre de doença e global em comparação ao grupo $\mathrm{CX}_{3} \mathrm{CR} 1$ positivo. Quanto aos pacientes com carcinoma de orofaringe e hipofaringe nenhuma associação pôde ser observada o que deixa claro que existam diferenças biológicas importantes entre as diferentes localizações de tumores de cabeça e pescoço. Contrário às nossas expectativas, o receptor CXCR5 não apresentou nenhuma correlação com a sobrevida dos pacientes.

Shulby et al. em 2004, realizaram um trabalho mostrando que a associação de $\mathrm{CX}_{3} \mathrm{CL} 1$ ao seu receptor, $\mathrm{CX}_{3} \mathrm{CR} 1$, ativa uma via antiapoptótica mediada por PI3K/Akt em linhagens prostáticas. Transpondo essa idéia para nosso trabalho no qual os pacientes $\mathrm{CX}_{3} \mathrm{CR} 1$ negativos apresentam uma melhor sobrevida, seria possível que neste grupo essa via esteja inativa. Assim sendo, as células tumorais estariam entrando em 
apoptose não conseguindo, dessa forma, disseminar pela corrente linfática formando focos de metástase nos linfonodos, conferindo uma melhor sobrevida para os pacientes (Shulby et al. 2004). Em outro estudo, realizado com 142 pacientes portadoras de câncer de mama, André et al. (2006) observaram uma correlação positiva entre a expressão de $\mathrm{CX}_{3} \mathrm{CR} 1$ e presença de metástases cerebrais. Em nosso trabalho, verificamos além da correlação com sobrevida, aumento do receptor $\mathrm{CX}_{3} \mathrm{CR} 1$ em linfonodos comprometidos, o que poderia nos fazer pensar na hipótese de que este receptor tenha algum papel no processo de metástases para os linfonodos.

O receptor CXCR5 já foi descrito como expresso em linhagens de carcinoma de pâncreas e de fígado, porém não encontramos estudos correlacionando-o com sobrevida em pacientes (Meijer et al. 2006).

Em relação ao receptor CXCR1, alguns trabalhos mostram a sua expressão em tumores HNSCC (Richards et al. 1997) e em linhagens celulares de carcinomas epidermóides de cavidade oral (Watanabe et al. 2002), o que condiz com nossos resultados e, além disso, verificamos um aumento na expressão do mRNA em tumores em relação à mucosa adjacente. Este receptor também está presente em várias linhagens celulares de câncer como cólon (Brew et al. 2000), pulmão (Zhu et al. 2004), e pâncreas (Kuwada et al. 2003) entre outros. Em imunohistoquímica de melanomas, CXCR1 não demonstrou estar correlacionado com prognóstico dos pacientes, porém em carcinoma de nasofaringe, CXCR1 foi correlacionado significantemente com a diminuição de sobrevida global ( $p=0.0045)$ (Varney et al. 2006, Horikawa et al. 2005). 
Neste trabalho, o único receptor cujo aumento está implicado tanto em tumores maiores pT3/T4 quanto nos tumores de pacientes com comprometimento linfonodal $(\mathrm{pN}+)$ em relação à mucosa é o CXCR3. Embora não tenhamos encontrado nenhum trabalho que envolva CXCR3 em tumores HNSCC, Ishikawa et al. (2006) descreveram recentemente a expressão tanto da proteína como do mRNA desse receptor nas oito linhagens derivadas de carcinoma epidermóide da cavidade oral estudadas. Em linhagens de melanoma, foi descrito que este receptor está presente e funcional e que a interação com seus ligantes seria capaz de ativar vias associadas à proliferação e à motilidade (Robledo et al. 2001), além de estar envolvido na diminuição da angiogênese do tumor (Pan et al. 2006).

Resumindo, entre os diversos receptores de quimiocinas estudados, observamos que existe um padrão diverso de expressão. Foram em média expressos em $50 \%$ das amostras, a exceção foi a expressão do mRNA de CXCR4 que foi observada em $100 \%$ das 98 amostras tumorais estudadas.

Outro dado encontrado foi o aumento do mRNA dos receptores CXCR1, CXCR3 e CXCR4 em tumores primários em relação à mucosa adjacente e somado a isto, observamos que os linfonodos comprometidos tiveram maior expressão de vários receptores: CXCR4, CXCR5, CCR7 e $\mathrm{CX}_{3} \mathrm{CR} 1$, o que concorda com a hipótese de que os receptores de quimiocinas possam ter um papel no processo de invasão tumoral. Não observamos correlações entre pacientes com e sem comprometimento de linfonodos. 
Além disto, a interação quimiotática entre CCR7 e de seu ligante CCL21, poderia ser um mecanismo de atração de células tumorais para os linfonodos em tumores de cavidade oral. Observamos também a possibilidade de que a negatividade da expressão do mRNA de CCR7 ou de $\mathrm{CX}_{3} \mathrm{CR} 1$ seja marcador candidato de uma melhor sobrevida para pacientes portadores de carcinoma epidermóide de cavidade oral. Já os demais ligantes de quimiocinas, não apresentaram correlações.

Os resultados obtidos neste trabalho podem colaborar com a hipótese de que em conjunto, a expressão dos mRNA de quimiocinas poderia ser utilizada como alvo molecular ou diagnóstico, ou ainda, servir de base para formação de novas hipóteses sobre $\mathrm{o}$ processo de progressão e metastatização em HNSCC. Porém futuros estudos ainda serão necessários para confirmar estes resultados. 
Conclusões 


\section{6- Conclusões}

De uma forma geral, nossos resultados sugerem que:

O receptor CXCR3 possa estar implicado na progressão tumoral em HNSCC, pois: verificamos seu aumento em tumores primários em relação à mucosa adjacente está aumentado em tumores maiores pT3/T4 em comparação com tumores pequenos pT1/T2 e está marginalmente aumentado nos tumores dos linfonodos comprometidos.

A interação quimiotática entre CCR7 e de seu ligante CCL21, possa ser um mecanismo de atração de células tumorais da cavidade oral para os linfonodos, uma vez que verificamos uma tendência ao aumento de expressão de CCL21 em linfonodos sugerindo que este possa ser um grande candidato a atrair as células tumorais que têm a expressão de CCR7.

A negatividade da expressão do mRNA de CCR7 ou de $\mathrm{CX}_{3} \mathrm{CR} 1$ seja marcador candidato de uma melhor sobrevida para pacientes com carcinoma epidermóide de cavidade oral, e que estes receptores possam vir a ser utilizados com marcadores prognósticos para pacientes portadores de HNSCC. 


\section{Referências}




\section{7- Referências}

Abeloff, M. D., Armitage, J. O., Lichter, A . S., Niederhuber, J. E., Clinical Oncology, Part III, Head and Neck, Second Edition, 2000.

Almofti A, Uchida D, Begum NM, Tomizuka Y, Iga $H$, Yoshida $H$, Sato M. The clinicopathological significance of the expression of CXCR4 protein in oral squamous cell carcinoma. Int J Oncol. 2004;25(1):65-71.

Andre F, Cabioglu N, Assi H, Sabourin JC, Delaloge S, Sahin A, Broglio K, Spano JP, Combadiere C, Bucana C, Soria JC, Cristofanilli M. Expression of chemokine receptors predicts the site of metastatic relapse in patients with axillary node positive primary breast cancer. Ann Oncol. 2006;17(6):945-51.

Bachelder RE.; Wendt MA and Mercurio AM.; Vascular Endothelial Growth Factor Promotes Breast Carcinoma Invasion in an Autocrine Manner by Regulanting the Chemokine Receptor CXCR4 - Cancer Research 2002; 62:7203-7206.

Bertolini F, Dell 'Agnola C, Mancuso P, Rabascio C, Burlini, A, Monestiroli S, Gobbi A, Pruneri G, and Martinelli G; CXCR4 Neutralization a Novel therapeutic Approach for Non-Hodgkin's Lymphoma, Cancer Res. 2002; 62: 3106-3112.

Brentani MM, Coelho FRG, Kowalski LP, Bases da Oncologia, Mecanismos de Invasão e Metástase, Segunda Edição, 2003.

Brew R, Erikson JS, West DC, Kinsella AR, Slavin J, Christmas SE. Interleukin-8 as an autocrine growth factor for human colon carcinoma cells in vitro. Cytokine. 2000; 12(1):78-85.

Burger JA, Burger M, and Kipps T, Chronic Lymphocytic B Cells Express Functional Cxcr4 Chemokine Receptors That Mediate Spontaneus 
Migration Beneath Bone Marrow Stromal Cells, Blood, 1999; 94 (11): 3658-3667.

Chomzynski P., Sacchi N., Single Step Method Of Rna Isolation By Acid Guanidium Thiocybate-Phenol-Cloroform Extraction. Analytical Biochem 1987;162:156-159.

Ding Y, Shimada Y, Maeda M, Kawabe A, Kaganoi J, Komoto I, Hashimoto $Y$, Miyake M, Hashida H, Imamura M. Association of CC chemokine receptor 7 with lymph node metastasis of esophageal squamous cell carcinoma. Clin Cancer Res. 2003; 9(9):3406-12.

Epstein RJ. The CXCL12-CXCR4 chemotactic pathway as a target of adjuvant breast cancer therapies.Nat Rev Cancer. 2004;4(11):901-9. Review.

Geminder H, Sagi-Assif O, Goldberg L, Meshel T, Rechavi G, Witz IP, and Ben-Baruch A; A Possible Role For Cxcr4 And Its Ligant, The Cxc Chemokine Stromal Cell-Derived Factor-1, In The Development Of Bone Marrow Metastases In Neuroblastoma, J. Immunology, 2001; 167: 4747-4757.

Gunn MD, Kyuwa S, Tam C, Kakiuchi T, Matsuzawa A, Williams LT, Nakano $H$. Mice lacking expression of secondary lymphoid organ chemokine have defects in lymphocyte homing and dendritic cell localization. J Exp Med. 1999;189(3):451-60.

Höpken EU.; Foss HD, Meyer D, Hinz M, Leder K, Stein H, and Lipp M, Up-Regulation Of The Chemokine Receptor Ccr7 In Classical But Not In Lymphocyte-Predominant Hodgkin Disease Correlates With Distainct Dissemination Of Neoplastic Cells In Lymphoid Organs. Blood, 2002; 99(4):1109-1116.

Horikawa T, Kaizaki Y, Kato H, Furukawa M, Yoshizaki T. Expression of interleukin-8 receptor A predicts poor outcome in patients with nasopharyngeal carcinoma. Laryngoscope. 2005;115(1):62-7. 
Hwang JH, Hwang JH, Chung HK, Kim DW, Hwang ES, Suh JM, Kim H, You KH, Kwon OY, Ro HK, Jo DY, Shong M. CXC chemokine receptor 4 expression and function in human anaplastic thyroid cancer cells. J Clin Endocrinol Metab. 2003;88(1):408-16.

Inca, Ministério Da Saúde (Www.Inca.Gov.Br), Estimativas 2006.

Ishikawa T, Nakashiro K, Hara S, Klosek SK, Li C, Shintani S, Hamakawa H. CXCR4 expression is associated with lymph-node metastasis of oral squamous cell carcinoma. Int J Oncol. 2006;28(1):61-6.

Jemal A, Siegel R, Ward E, Murray T, Xu J, Smigal C, Thun MJ. Cancer statistics, 2006. CA Cancer J Clin. 2006;56(2):106-30.

Kakinuma T, Hwang ST. Chemokines, chemokine receptors, and cancer metastasis. J Leukoc Biol. 2006;79(4):639-51. Review.

Kijima T, Maulik G, Ma PC, Tibaldi EV, Turner RE, Rollins B, Satller M, Johnson BE and Salgia R; Regulation Of Cellular Proliferation, Cytoskeletal Function, And Signal Transduction Through Cxcr4 And C-Kit In Small Cell Lung Cancer Cells - Cancer Research 2002; 62:6304-6311.

Kulbe H, Levinson NR, Balkwill F, Wilson JL. The chemokine network in cancer--much more than directing cell movement. Int $\mathrm{J}$ Dev Biol. 2004;48(5-6):489-96. Review.

Kuwada Y, Sasaki T, Morinaka K, Kitadai Y, Mukaida N, Chayama K. Potential involvement of IL-8 and its receptors in the invasiveness of pancreatic cancer cells. Int J Oncol. 2003;22(4):765-71.

Landis SH, Murrayt Bolden S, Wingo PA, Cancer Statistics, $1999 \mathrm{Ca}$ Cancer J Clin 1999; 49: 8-12.

Liotta, L. A., An Atractive Force In Metastasis. Nature, 2001; 410: 24-25. 
Luster AD, Chemokines - Chemotatic Cytokines That Mediate Inflammation, N. Engl. J. Med 1998; 338(7): 436-445.

Mashino K, Sadanaga N, Yamaguchi H, Tanaka F, Ohta M, Shibuta K, Inoue $\mathrm{H}$, Mori M. Expression of chemokine receptor CCR7 is associated with lymph node metastasis of gastric carcinoma. Cancer Res. 2002;62(10):2937-41.

Meijer J, Zeelenberg IS, Sipos B, Roos E. The CXCR5 Chemokine Receptor Is Expressed by Carcinoma Cells and Promotes Growth of Colon Carcinoma in the Liver. Cancer Res. 2006 Oct 1;66(19):9576-82.

Muller A, Homey B, Soto H, Ge N, Catron D, Buchanan ME, McClanahan T, Murphy E, Yuan W, Wagner SN, Barrera JL, Mohar A, Verastegui E, Zlotnik A. Involvement of chemokine receptors in breast cancer metastasis. Nature. 2001;410(6824):50-6.

Muller A, Sonkoly E, Eulert C, Gerber PA, Kubitza R, Schirlau K, FrankenKunkel P, Poremba C, Snyderman C, Klotz LO, Ruzicka T, Bier H, Zlotnik A, Whiteside TL, Homey B, Hoffmann TK. Chemokine receptors in head and neck cancer: association with metastatic spread and regulation during chemotherapy. Int J Cancer. 2006;118(9):2147-57.

Multiple Actions Of The Chemokine Cxcl12 On Epithelial Tumor Cells In Human Ovarian Cancer - Cancer Research 2002; 62: 5930-5938.

Murphy PM; Chemokines And The Molecular Basis Of Cancer Metastasis, N. Engl. J. Med., 2001; 345(11): 833-835. Nci National Cancer Institute. Www.Cancer.Gov/Cancer

Pan J, Burdick MD, Belperio JA, Xue YY, Gerard C, Sharma S, Dubinett SM, Strieter RM. CXCR3/CXCR3 ligand biological axis impairs RENCA tumor growth by a mechanism of immunoangiostasis. J Immunol. 2006;176(3):1456-64. 
Parkin DM, Bray F, Ferlay J, Pisani P. Global cancer statistics, 2002. CA Cancer J Clin. 2005;55(2):74-108.

Porter DA, Krop IE, Nasser S, Sgroi D. Kaelin CM, Marks JR, Riggins G and Polyak, K. A Sage (Serial Analisis Of Gene Expression) View Of Breast Tumor Progression. Cancer Res. 2001; 61: 5697-5702.

Richards BL, Eisma RJ, Spiro JD, Lindquist RL, Kreutzer DL. Coexpression of interleukin-8 receptors in head and neck squamous cell carcinoma. Am J Surg. 1997;174(5):507-12.

Robledo MM, Bartolome RA, Longo N, Rodriguez-Frade JM, Mellado M, Longo I, van Muijen GN, Sanchez-Mateos P, Teixido J. Expression of functional chemokine receptors CXCR3 and CXCR4 on human melanoma cells. J Biol Chem. 2001;276(48):45098-105.

Samara GJ, Lawrence DM, Chiarelli CJ, Valentino MD, Lyubsky S, Zucker S, Vaday GG. CXCR4-mediated adhesion and MMP-9 secretion in head and neck squamous cell carcinoma. Cancer Lett. 2004; 214(2): $231-41$.

Schrader AJ, Lechner O, Templin M, Dittmar KE, Machtens S, Mengel M, Probst-Kepper M, Franzke A, Wollensak T, Gatzlaff P, Atzpodien J, Buer $\mathrm{J}$, Lauber CXCR4/CXCL12 expression and signalling in kidney cancer. $\mathrm{Br}$ J Cancer. 2002;86(8):1250-6.

Scotton CJ, Wilson JL, Scott K, Stamp G, Wilbanks GD, Fricker S, Bridger G, Balkwill FR. Multiple actions of the chemokine CXCL12 on epithelial tumor cells in human ovarian cancer. Cancer Res. 2002; 62(20): 5930-8.

Scotton CJ, Wilson JL, Miliken D, Stamp G and Balkwill, F. R.; Epithelial Cancer Cell Migration: A Role For Chemokine Receptors? Cancer Res., 2001; 61: 4961-4965. 
Shulby SA, Dolloff NG, Stearns ME, Meucci O, Fatatis A. CX3CR1fractalkine expression regulates cellular mechanisms involved in adhesion, migration, and survival of human prostate cancer cells. Cancer Res. 2004; 64(14): 4693-8.

Spohnc Support For People With Oral And Head And Neck Cancer. Www.Spohnc.Org/Intro.

Taichman RS, Cooper C, Keller ET, Pienta KJ, Taichman NS, McCauley LK. Use of the stromal cell-derived factor-1/CXCR4 pathway in prostate cancer metastasis to bone. Cancer Res. 2002; 62(6): 1832-7.

Takanami I;. Overexpression Of Ccr7 mRNA In Nonsmall Cell Lung Cancer: Correlation With Lymph Nodes Metasatasis - Int J Cancer, 2003; Issue 2: 186-189.

Till KJ, Lin K, Zuzel M and Cawley, J. C.; The Chemokine Receptor Ccr7 And $\alpha 4$ Integrin Are Important For Migration Of Chronic Limphocitic Leukemia Cells Into Lymph Nodes. Blood, 2002; 99(8): 2977-2984.

Uchida D, Begum NM, Almofti A, Nakashiro K, Kawamata H, Tateishi Y, Hamakawa H, Yoshida H, Sato M. Possible role of stromal-cell-derived factor-1/CXCR4 signaling on lymph node metastasis of oral squamous cell carcinoma. Exp Cell Res. 2003; 290(2): 289-302.

Uchida D, Begum NM, Tomizuka Y, Bando T, Almofti A, Yoshida H, Sato M. Acquisition of lymph node, but not distant metastatic potentials, by the overexpression of CXCR4 in human oral squamous cell carcinoma. Lab Invest. 2004; 84(12): 1538-46.

UICC, Manual De Oncologia Clínica, Fosp, 6ª.Edição, 1999.

Varney ML, Johansson SL, Singh RK. Distinct expression of CXCL8 and its receptors CXCR1 and CXCR2 and their association with vessel density and aggressiveness in malignant melanoma. Am J Clin Pathol. 2006;125(2):209-16. 
Vokes EE; Combined- Modality Therapy Of Head And Neck Cancer. Oncology 1997;(Huntingt) 11 (9 Suppl9) : 27-30.

Wang J, Xi L, Hunt JL, Gooding W, Whiteside TL, Chen Z, Godfrey TE, Ferris RL. Expression pattern of chemokine receptor 6 (CCR6) and CCR7 in squamous cell carcinoma of the head and neck identifies a novel metastatic phenotype. Cancer Res. 2004; 64(5): 1861-6.

Watanabe $\mathrm{H}$, Iwase $\mathrm{M}$, Ohashi $\mathrm{M}$, Nagumo $\mathrm{M}$. Role of interleukin-8 secreted from human oral squamous cell carcinoma cell lines. Oral Oncol. 2002; 38(7): 670-9.

Zhou Y, Larsen PH, Hao C, Yong VW. CXCR4 is a major chemokine receptor on glioma cells and mediates their survival. J Biol Chem. 2002; 277(51): 49481-7.

Zhu YM, Webster SJ, Flower D, Woll PJ. Interleukin-8/CXCL8 is a growth factor for human lung cancer cells. Br J Cancer. 2004; 91(11): 1970-6.

Zlotnik A. Chemokines in neoplastic progression. Semin Cancer Biol. 2004; 14(3):181-5. 
Apêndices 


\section{Apêndice I}

\begin{tabular}{|c|c|c|c|}
\hline $\begin{array}{l}\text { Nome usado } \\
\text { na tese: }\end{array}$ & $\begin{array}{l}\text { Símbolo } \\
\text { oficial: }\end{array}$ & Nome oficial: & Outros símbolos ou nomes usados: \\
\hline CXCR1 & ILR8A & $\begin{array}{l}\text { Receptor de } \\
\text { interleucina } 8 \mathrm{~A}\end{array}$ & $\begin{array}{l}\text { C-C, C-C CKR-1, C-C-CKR-1, CD128, } \\
\text { CD181, CDw128a, CKR-1, CMKAR1, } \\
\text { CXCR1, IL8R1, IL8RBA IL-8 receptor; } \\
\text { IL-8 receptor type 1; chemokine (C-X-C } \\
\text { motif) receptor 1; chemokine (C-X-C) } \\
\text { receptor 1; high affinity interleukin-8 } \\
\text { receptor A; interleukin } 8 \text { receptor alpha; } \\
\text { interleukin-8 receptor type 1; interleukin- } \\
8 \text { receptor type A }\end{array}$ \\
\hline CXCR2 & ILR8B & $\begin{array}{l}\text { Receptor de } \\
\text { interleucina } 8 \text { B }\end{array}$ & $\begin{array}{l}\text { CD182, CDw128b, CMKAR2, CXCR2, } \\
\text { IL8R2, IL8RA } \\
\text { CXCR2 gene for IL8 receptor type B; } \\
\text { GRO/MGSA receptor; chemokine (C-X- } \\
\text { C motif) receptor 2; chemokine (CXC) } \\
\text { receptor 2; high affinity interleukin-8 } \\
\text { receptor B; interleukin } 8 \text { receptor B; } \\
\text { interleukin } 8 \text { receptor beta; interleukin } 8 \\
\text { receptor type 2; interleukin-8 receptor } \\
\text { type B }\end{array}$ \\
\hline CXCR3 & CXCR3 & $\begin{array}{l}\text { Receptor de } \\
\text { quimiocina } \\
\text { CXC } 3\end{array}$ & $\begin{array}{l}\text { CD182, CD183, CKR-L2, CMKAR3, } \\
\text { GPR9, IP10, IP10-R, Mig-R, MigR } \\
\text { G protein-coupled receptor 9; IP10 } \\
\text { receptor; Mig receptor; chemokine (C-X- } \\
\text { C) receptor } 3\end{array}$ \\
\hline CXCR4 & CXCR4 & $\begin{array}{l}\text { Receptor de } \\
\text { quimiocina } \\
\text { CXC } 4\end{array}$ & $\begin{array}{l}\text { CD184, D2S201E, FB22, HM89, } \\
\text { HSY3RR, LAP3, LCR1, LESTR, } \\
\text { NPY3R, NPYR, NPYRL, NPYY3R, } \\
\text { WHIM } \\
\text { C-X-C chemokine receptor type 4; } \\
\text { CD184 antigen; chemokine (C-X-C } \\
\text { motif), receptor } 4 \text { (fusin); chemokine } \\
\text { receptor 4; fusin; leukocyte-derived } \\
\text { seven-transmembrane-domain receptor; } \\
\text { lipopolysaccharide-associated protein 3; } \\
\text { neuropeptide Y receptor Y3; seven } \\
\text { transmembrane helix receptor; seven- } \\
\text { transmembrane-segment receptor, spleen; } \\
\text { stromal cell-derived factor } 1 \text { receptor }\end{array}$ \\
\hline CXCR5 & BLR1 & $\begin{array}{l}\text { Receptor de } \\
\text { limfoma de } \\
\text { Burkitt } 1\end{array}$ & $\begin{array}{l}\text { CD185, CXCR5, MDR15, MGC117347 } \\
\text { Burkitt lymphoma receptor 1; Burkitt } \\
\text { lymphoma receptor 1, GTP-binding } \\
\text { protein; Burkitt lymphoma receptor 1, } \\
\text { isoform 1; C-X-C chemokine receptor } \\
\text { type 5; monocyte-derived receptor } 15\end{array}$ \\
\hline
\end{tabular}




\begin{tabular}{|c|c|c|c|}
\hline CCR7 & CCR7 & $\begin{array}{l}\text { Receptor de } \\
\text { quimiocina CC } 7\end{array}$ & $\begin{array}{l}\text { BLR2, CD197, CDw197, CMKBR7, } \\
\text { EBI1 } \\
\text { C-C chemokine receptor type 7; CC } \\
\text { chemokine receptor 7; EBV-induced G } \\
\text { protein-coupled receptor 1; Epstein-Barr } \\
\text { virus induced G-protein coupled receptor; } \\
\text { Epstein-Barr virus induced gene 1; MIP-3 } \\
\text { beta receptor; chemokine (C-C) receptor } \\
\text { 7; lymphocyte-specific G protein-coupled } \\
\text { peptide receptor }\end{array}$ \\
\hline CX3CR1 & CX3CR1 & $\begin{array}{l}\text { Receptor de } \\
\text { quimiocina } \\
\text { CX3C } 1\end{array}$ & $\begin{array}{l}\text { CCRL1, CMKBRL1, CMKDR1, GPR13, } \\
\text { GPRV28, V28 } \\
\text { Other Designations: G protein-coupled } \\
\text { receptor 13; chemokine (C-C) receptor- } \\
\text { like 1; chemokine (C-X3-C) receptor } 1\end{array}$ \\
\hline CXCL12 & CXCL12 & $\begin{array}{l}\text { Ligante de } \\
\text { Quimiocina } 12\end{array}$ & $\begin{array}{l}\text { PBSF, SCYB12, SDF-1a, SDF-1b, SDF1, } \\
\text { SDF1A, SDF1B, TLSF-a, TLSF-b, } \\
\text { TPAR1, chemokine } \\
\text { stromal cell-derived factor 1; stromal } \\
\text { cell-derived factor } 1 \text { delta; stromal cell- } \\
\text { derived factor } 1 \text { gamma; stromal cell- } \\
\text { derived factor 1a }\end{array}$ \\
\hline CCL19 & CCL19 & $\begin{array}{l}\text { Ligante de } \\
\text { Quimiocina } 19\end{array}$ & $\begin{array}{l}\text { CKb11, ELC, MGC34433, MIP-3b, } \\
\text { MIP3B, SCYA19 } \\
\text { CC chemokine ligand 19; CK beta-11; } \\
\text { EBI1-ligand chemokine; } \\
\text { OTTHUMP00000000531; beta } \\
\text { chemokine exodus-3; exodus-3; } \\
\text { macrophage inflammatory protein 3-beta; } \\
\text { small inducible cytokine A19; small } \\
\text { inducible cytokine subfamily A (Cys- } \\
\text { Cys), member } 19\end{array}$ \\
\hline CCL21 & CCL21 & $\begin{array}{l}\text { Ligante de } \\
\text { quimiocina } 21\end{array}$ & $\begin{array}{l}\text { 6Ckine, CKb9, ECL, MGC34555, } \\
\text { SCYA21, SLC, TCA4 } \\
\text { Efficient Chemoattractant for } \\
\text { Lymphocytes; OTTHUMP00000000526; } \\
\text { OTTHUMP00000000527; beta } \\
\text { chemokine exodus-2; exodus-2; } \\
\text { secondary lymphoid tissue chemokine; } \\
\text { small inducible cytokine A21; small } \\
\text { inducible cytokine subfamily A (Cys- } \\
\text { Cys), member } 21\end{array}$ \\
\hline CX3CL1 & CX3CL1 & $\begin{array}{l}\text { Ligante de } \\
\text { quimiocina } \\
\text { CX3C } 1\end{array}$ & $\begin{array}{l}\text { ABCD-3, C3Xkine, CXC3, CXC3C, } \\
\text { NTN, NTT, SCYD1, fractalkine, } \\
\text { neurotactin } \\
\text { small inducible cytokine subfamily D } \\
\text { (Cys-X3-Cys), member 1; small inducible } \\
\text { cytokine subfamily D (Cys-X3-Cys), } \\
\text { member } 1 \text { (fractalkine, neurotactin); } \\
\text { small inducible cytokine subfamily D } \\
\text { (Cys-X3-Cys), member-1 }\end{array}$ \\
\hline
\end{tabular}




\section{Apêndice II}

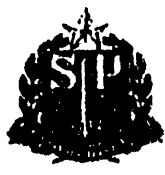

HOSPITAL DAS CLINICAS

UA FaCiUIIJAdE DE MEDICINA DA UNIVERSIOAdE de SAO PAULC

CAIXA POSTAI., BO91 - SAO PAULO - BRASIL

DIRETORIA CLÍNICA

Comissão de Ética para Análise de Projetos de Pesquisa

\section{APROVAÇÃO}

A Comissão de Ética para Análise de Projetos de Pesquisa - CAPPesq da Diretoria Clínica do Hospital das Clínicas e da Faculdade de Medicina da Universidade de São Paulo, em sessão de 09.04.03, APROVOU - Protocolo de Pesquisa $n^{\circ}$ 041/03, intitulado: "Correlação das quimiocinas CXCL12, CCL19 e CCL21 e de seus respectivos receptores CXCR4 e CCRT em relação a invasão de linfonodos nos carcinomas epidermóides em cabeça e pescoço" apresentudo pelo Departamento de RADIOLOGIA, bem como n Termo de Consentimento Livre e Esclarecido.

Pesquisador(a) Responsável: PROFA. DRA. MIRIAM HATSUE HONDA FEDERICO

Pesquisador(a) Executante: DRA. CRISTINA MARIA MEIRELES CAMPOFIORITO

CAPPesq, 09 de Abril de 2003.

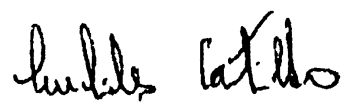

PROF. DR. EUCLIDES AYRES DE CASTILHO

Presidente da Comissão Ética para Análise

de Projetos de Pesquisa

OBSERVAÇÃO: Cabe ao pesquisador elaborar e apresentar d CAPPesq. os ralatdrlos parcials final sobre a pesquisa (Resolucto do Conselho Nacional de Savide $n^{\circ}$ 196. de 10.10.1996, inciso IX.2, letra "c") 


\section{GOVERNO DO ESTADO DE SÃo PAULO Secretaria de Estado da Saúde HOSPHEL - Complexo Hospitalar Heliópolis SERVIÇO DE CIRURGIA DE CABEÇA E PESCOÇO}

Rua Cônogo Xavier, n' 276 - $9^{\circ}$ and ur - Balrro Bacomh - 8ho Paulo - 8P - CEP - 04231-030

Tel. 274-7600 -ramal 216- Tel: 55-11- 6914-5576 -

São Paulo, 14de fevereiro de 2002

\section{DECLARAÇÃO}

Declaro, para os devidos fins, que o Dr. Fernando Walder, membro titular do Serviço de Cirurgia de Cabeça e Pescoço do Hospital Heliópolis, está autorizado a utilizar os dados de prontuários, bem como o material biológico coletado de pacientes do Serviço, na elaboração de trabalho científico a ser desenvolvido em conjunto com a Disciplina de Oncologia da Faculdade de Medicina da Universidade de São Paulo que culminará com a sua Tese de Doutoramento.

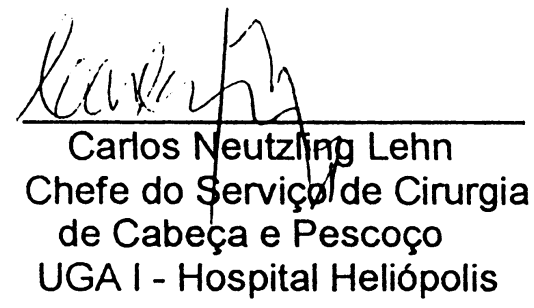

